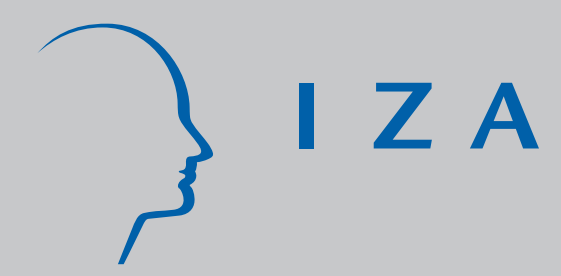

IZA DP No. 5

Labor Force Transitions of Older Married Couples in Germany

David M. Blau

Regina T. Riphahn

May 1998 


\title{
LABOR FORCE TRANSITIONS OF OLDER MARRIED COUPLES IN GERMANY
}

\author{
David M. Blau \\ Regina T. Riphahn
}

Discussion Paper No. 5
May 1998

IZA

P.O. Box 7240

D-53072 Bonn

Germany

Tel: +49-228-3894-201

Fax: +49-228-3894-210

Email: iza@iza.org

This Discussion Paper is issued within the framework of IZA's research area The Welfare State and Labor Markets. Any opinions expressed here are those of the author(s) and not those of the institute. Research disseminated by IZA may include views on policy, but the institute itself takes no institutional policy positions.

The Institute for the Study of Labor (IZA) in Bonn is a local and virtual international research center and a place of communication between science, politics and business. IZA is an independent, nonprofit limited liability company (Gesellschaft mit beschränkter Haftung) supported by the Deutsche Post AG. The center is associated with the University of Bonn and offers a stimulating research environment through its research networks, research support, and visitors and doctoral programs. IZA engages in (i) original and internationally competitive research in all fields of labor economics, (ii) development of policy concepts, and (iii) dissemination of research results and concepts to the interested public. The current research program deals with (1) mobility and flexibility of labor markets, (2) internationalization of labor markets and European integration, (3) the welfare state and labor markets, (4) labor markets in transition, (5) the future of work, and (6) general labor economics.

IZA Discussion Papers often represent preliminary work and are circulated to encourage discussion. Citation of such a paper should account for its provisional character. 
IZA Discussion Paper No. 5

May 1998

\section{ABSTRACT}

\section{Labor Force Transitions of Older Married Couples in Germany*}

This study investigates the labor force behavior of older married couples in Germany. Monthly observations from the first eleven waves of the German Socio-Economic Panel (GSOEP) are used to describe and analyze the relationship between the labor force behavior of husbands and wives. The empirical model is a discrete time, competing risks hazard model of transitions among labor force states defined by the employment status of both spouses. The analysis indicates that the probability of one spouse exiting employment is much larger if the other spouse is not employed than if the other spouse is employed. Similarly, one member of a couple is much more likely to enter employment if the spouse is employed than if the spouse is not employed. Observed covariates including wages and retirement benefits help to explain these patterns, but unobserved preferences for shared leisure also appear to play an important role.

JEL Classification: H55, J26

Keywords: labor force transition, retirement, household decision-making, competing risks hazard model

Regina T. Riphahn

SELAPO

University of Munich

Ludwigstr. 28

D - 80539 München

Germany

Tel.: + 49-89-2180 2128

Fax: + 49-89-33 6392

email: Regina.Riphahn @selapo.vwl.uni- muenchen.de

* The authors acknowledge helpful comments from participants at the conference on "Economics of Aging - International Health and Retirement Surveys Conference," Amsterdam, August 1997. 


\section{Introduction}

The labor force participation rate of married women has increased substantially in most developed countries in the last three to four decades. Participation increases have been strongest at younger ages but have been large at older ages as well. For example, the participation rate of married West German women aged 55 to 60 rose from 31.7 to about 40 percent between 1985 and $1994^{1}$ (Bundesminister, 1996). A similar pattern in the United States was documented by Perrachi and Welch (1994). As a result of this trend, it is increasingly common for both spouses in married couples to be employed as they approach the typical age range of retirement from the labor force. This raises interesting questions about the relationship between the labor force behavior of husbands and wives in older married couples. Does the employment status of one spouse affect the labor force transition behavior of the other spouse? What is the role of financial incentives in these transition decisions? Are the effects of economic variables symmetric, or do the characteristics of husbands affect the behavior of wives differently from the way wives' characteristics affect their husbands' behavior? How do health and age of the spouses affect these relationships? Is there evidence that past labor force decisions affect current behavior?

These and related questions are of inherent scientific interest, but are also potentially important for public policy. Recent reforms and proposed changes in public pension plans in many countries will alter the incentives and opportunities for husbands and wives to coordinate their labor force behavior. The financial and labor market impact of such reforms will depend in part on the relationship between the labor force behavior of older spouses, so understanding this behavior is important.

${ }^{1}$ Official statistics show a 43 percent labor force participation rate for married women in 1994. However, changes in the survey instrument in 1990 caused an increase in the measured female labor force participation rate by 2.3 percentage points. For details see Heidenreich (1991). 
In this paper we use monthly observations from the first eleven waves of the German Socio-Economic Panel (GSOEP) to describe and analyze the relationship between the labor force behavior of husbands and wives in Western Germany. Wagner (1996) shows that among German couples in which both spouses have a long-term attachment to the labor force, ten percent of husbands and wives exit the labor force in the same year and 40 percent within three years of each other. ${ }^{2}$ This is quite similar to patterns found in the United States (Hurd, 1990; Blau, 1997; Gustman and Steinmeier, 1994). However, a description and analysis of the entire distribution of joint labor force behavior of married couples in Germany and of its determinants has not yet been provided; existing studies focus almost exclusively on the behavior of couples in which the husband and wife both have a strong attachment to the labor force. We do not select our sample based on previous labor force behavior, and thereby avoid the potential sample selection bias present in previous studies. We estimate a model that permits rich patterns of dynamics, allowing us to characterize the relationship between the labor force behavior of older spouses more thoroughly than in previous studies. Our model contains an extensive set of covariates measuring financial incentives, health, and preferences, and controls for unobserved couple-specific heterogeneity.

Our empirical findings show that there are strong patterns of dependence between the employment transitions of one spouse and the employment status of the other spouse. The probability of one spouse exiting employment is much larger if the other spouse is not employed than if the other spouse is employed. Similarly, one member of a couple is much more likely to enter employment if the spouse is employed than if the spouse is not employed. Observed covariates including wages and retirement benefits help explain these patterns, but unobserved preferences for shared leisure also play a major role.

${ }^{2}$ See also Wagner (1991), Pischner and Wagner (1992), Allmendinger (1990), and Giannelli (1996). 
Section 2 provides a brief overview of the regulations affecting couples' retirement in Germany. Section 3 describes the conceptual basis for the analysis and the econometric model. Section 4 describes the data, and section 5 presents and discusses the estimation results. Conclusions are given in section 6 .

\section{Public Pensions in Germany}

The central features of the German public pension system have been in place since 1957. Every worker pays a fixed proportion of gross income (up to a maximum taxable level) into the system. This contribution is matched by employers. Retirement benefits are a function of lifetime contributions to the pension system. Those who contributed more because of higher earnings or a longer contribution period receive higher benefits. The average replacement rate is about 60 percent of lifetime average income, net of taxes. This is substantially higher than the average net replacement rate in the United States Social Security system, which is under 50 percent (ignoring spouse benefits). Compared to the United States, the German retirement system is not very progressive, with the replacement rate declining only moderately as income rises. With the exception of survivors' benefits, there are no special regulations regarding couples. Individual benefits are not adjusted for the presence of a spouse or other dependents, unlike in the United States Social Security system. In households in which both spouses qualify for public pension benefits, benefits are paid based on the individual contributions of husband and wife. There is no benefit reduction for couples. ${ }^{3}$

For the period under investigation in this study the minimum age at which a non-

${ }^{3}$ Private pensions provided by firms are common in Germany, but they provide much smaller benefits than in most other industrialized countries. A 1990 survey indicated that about 65 percent of German employees are covered by a firm pension. The payments from such pension programs are small: About 52 percent of all recipients receive less than DM 200 per month, and another 14 percent receive between DM 200 and 300 (Heppt, 1995). On average pensions make up less than six percent of retirement income. 
disabled woman could receive retirement benefits was 60. To qualify for retirement benefits at age 60 she must have contributed to the public retirement plan for at least 15 years of which at least 10 years must have been accumulated after age 40. In general, men could not receive retirement benefits before age 63 ('retirement after long-term contributions'), which required 35 contribution years. For men with fewer than 35 contribution years and women with fewer than 15 contribution years the age at which benefits could be received was 65 .

There are three exceptions to these general rules: For disabled individuals there is no minimum retirement age; for the severely handicapped with at least 35 contribution years and for 'long-term unemployed' workers the minimum retirement age was $60 .{ }^{4}$ Unemployed workers who have reached age 60 and who have been unemployed for at least 12 out of the previous 18 months can claim retirement benefits if they have accumulated at least 15 contribution years and if they have contributed to the retirement insurance system during eight of the previous ten years. Recent unemployment rates for workers aged 55-59 in the Western states of Germany have been almost double the overall West German unemployment rates for men of all ages. This is believed to be related to the fact that the long-term unemployed may begin to receive retirement benefits at age 60. It is common for firms to lay off an older worker as many months before age 60 as the worker's unemployment benefits will run (up to 32 months since 1987). Until the worker reaches age 60, he or she receives public unemployment benefits which are at times supplemented by voluntary one time lump-sum or regular monthly payments from the former employer (Jacobs, et al., 1991). ${ }^{5}$

\footnotetext{
${ }^{4}$ In order to qualify for disability retirement individuals must have contributed for at least five years to the retirement insurance including three of the last five years. In addition they have to provide a physician's medical recommendation. Over 60 percent of all disability-retirement applicants have been granted benefits.

${ }^{5}$ Frequently the term 'pre-retirement' is used in a description of German retirement entry rules, but this term has no precise definition. It is sometimes used to characterize a situation in which an individual is unemployed, and collecting unemployment insurance benfits, possibly with
} 
The Retirement Reform of 1992 mandated a phased increase in the minimum age at which full retirement benefits can be received for women, the long term unemployed, and 35year contributors. New early retirement regulations allow individuals to retire prior to age 65 in exchange for a benefit reduction, and encourage part-time work by the elderly. The German retirement system is likely to undergo further reforms as a result of population aging: BörschSupan (1997) calculated that in order to maintain current replacement rates, the contribution rate would have to increase from the current rate of about 20 percent of gross earnings (shared by employers and employees) to about 35 percent. Thus, coordination of labor force behavior of married couples may increase in importance in the future as greater flexibility is introduced in the public pension system in Germany.

\section{An Econometric Model of Employment Transitions of Older Couples}

The traditional approach to analyzing labor force behavior of married couples is based on the family labor supply model, in which behavior is determined by maximization of a single utility function subject to a family budget constraint in which income is pooled and the allocation of consumption between the spouses is not modeled. ${ }^{6}$ This approach has obvious limitations that have been widely noted: the spouses may have different preferences, making it difficult to justify aggregating preferences; and they may have different outside opportunities, making it difficult to justify pooling income (Chiappori, 1988; Kooreman and Kapteyn, 1990; McElroy, 1990). Nevertheless, the family labor supply model is still commonly used because

additional payments from a former employer. It may be used to refer to individuals who receive disability retirement benefits, and it may be applied to describe severely handicapped individuals who retired after reaching age 60 . If one uses working until age 63 or 65 as a reference point for regular retirement, then even women who started to receive old-age retirement benefits at age 60 may be pre-retired.

${ }^{6}$ See Killingsworth and Heckman (1986) for a thorough description of the model, and van Soest (1995) for a recent empirical application. 
it is simple and has less stringent data requirements than bargaining models based on cooperative game theory, such as McElroy and Horney (1981), Manser and Brown (1980), and Chiappori $(1988,1992)$. Our analysis is mainly descriptive, so we do not propose a specific behavioral model as a basis for the estimation. We specify an econometric model that is flexible enough to be considered as an approximation to the employment decision rules derived from either a dynamic family labor supply model or a dynamic cooperative bargaining model. The specification allows for the possibility that income is not pooled. We do not assume that the parameters of the model can be interpreted as preference parameters; rather, we recognize that they may represent some combination of the preferences of the husband, the preferences of the wife, the relative bargaining power of the husband and wife, and expectations of future random variables. We do not attempt to identify structural parameters from the approximation model - such a task is difficult in a static model of the behavior of couples and has to our knowledge not been attempted in a dynamic model.

We define four discrete states based on the employment status of the husband and wife:

1: Both spouses are employed;

2: The husband is employed, the wife is not employed;

3: The husband is not employed, the wife is employed;

4: Both spouses are not employed.

Including part time work as a separate state would be of considerable interest, but the resulting model has nine states with far too many infrequently observed transitions to make estimation feasible. It would also be of interest to allow unemployment and nonparticipation in the labor force to be distinct states, but for similar reasons this is not feasible. Therefore we consider transitions among states defined only by employment and nonemployment. Cases in which both spouses change employment status in the same month are rare: of almost 1,400 
transitions observed in the data, only 25 involved both spouses changing employment status in the same month. Such a small number of joint transitions makes it infeasible to model the determinants of such transitions. Therefore, we reclassify these 25 cases so that one of the spouses is assumed to change employment status in the month before the transition month reported in the survey. In other words, joint transitions are reclassified to yield a sequence in which one spouse changes states in the month following the other spouse's transition. See the Appendix for details.

Let $\mathrm{y}_{\mathrm{ijk} \text { t }}$ represent the expected present discounted value (EPDV) of making a transition from state $\mathrm{i}$ to state $\mathrm{j}$ for couple $\mathrm{k}$ currently in the $\mathrm{t}$ 'th period of their $\ell^{\prime}$ th observed spell. If behavior is determined by a family labor supply model then y can be interpreted as discounted utility. In a bargaining model y can be thought of as a measure of the couple's social welfare, with the weights placed on each spouse's utility implicitly determining the form of the social welfare function. As indicated above, we do not specify a structural model; rather we specify a linear approximation to the underlying function that determines y:

$$
y_{i j k \ell t}=E_{k t} \alpha_{i j}+X_{k t} \beta_{1 i j}+S_{k \ell} \beta_{2 i j}+f(t) \beta_{3 i j}+Z_{k t} \beta_{4 i j}+\rho_{1 i j} \mu_{k}+\rho_{2 i j} \delta_{k \ell}+\varepsilon_{i j k \ell t}
$$

where

$\mathrm{E}_{\mathrm{kt}}=\mathrm{a}$ vector of wage and retirement benefit variables.

$\mathrm{X}_{\mathrm{kt}}=\mathrm{a}$ vector of exogenous regressors, some of which may not depend on $\mathrm{t}$.

$\mathrm{S}_{\mathrm{k} \ell}=$ a vector of lagged dependent variables such as the state occupied in the previous spell.

$f(t)=a$ vector of indicators of the duration of the current spell.

$\mathrm{Z}_{\mathrm{kt}}=\mathrm{a}$ vector of potentially endogenous variables.

$\mu_{\mathrm{k}}$ and $\delta_{\ell}=$ permanent, and spell-specific error components.

$\epsilon_{\mathrm{ijk} \ell t}=$ a serially independent shock 
$\alpha$ 's, $\beta$ 's, and $\rho$ 's = parameters to be estimated.

This formulation is quite flexible. All of the parameters are transition-specific. The effects of wages are allowed to differ from the effects of retirement benefits, and the effects of one spouse's wage (benefit) are allowed to differ from the effects of the other spouse's wage (benefit). Specifications in which various restrictions on the $\alpha$ 's are imposed are estimated and tested. Duration dependence, state dependence, and history dependence are all incorporated, with the particular form taken by each determined by specification tests. Two forms of unobserved heterogeneity are incorporated, including a permanent error component, and a spell-specific component. The error components have transition-specific parameters ( $\rho$ 's) and are treated as random effects with discrete distributions, the parameters of which are estimated along with the other parameters of the model. This provides a very rich specification of unobserved heterogeneity, a potentially important consideration in obtaining consistent parameter estimates.

For computational tractability, we assume that $\epsilon_{\mathrm{ijk} k \mathrm{t}}$ follows the extreme value distribution. The probability that couple $\mathrm{k}$ makes a transition from state $\mathrm{i}$ to state $\mathrm{j}$ after the t'th period of the $\ell^{\prime}$ th spell, conditional on the error components, is therefore

$$
\mathrm{P}_{\mathrm{ijklt}}\left(\mu_{\mathrm{k}}, \delta_{\mathrm{k} \ell}\right)=\frac{\exp \left(\overline{\mathrm{y}}_{\mathrm{ijk \ell \ell}}\right)}{\sum_{\mathrm{r}=1, \mathrm{r} \neq \mathrm{j}(\mathrm{i})}^{4} \exp \left(\overline{\mathrm{y}}_{\text {irk } \ell \mathrm{t}}\right)} \text {, with } \mathrm{j}(1)=4, \mathrm{j}(2)=3, \mathrm{j}(3)=2, \mathrm{j}(4)=1 \text {, }
$$

with $\bar{y}_{\mathrm{ijk} k t}=\mathrm{y}_{\mathrm{ijk} k t}-\epsilon_{\mathrm{ijk} \ell t}$, and $\mathrm{j}(\mathrm{)})$ denoting the absence of joint transitions in the data due to the reclassification described above. Conditional on the error components, the model consists of four multinomial logit equations for transitions from the four labor force states defined above, with three possible outcomes for each origin state: the husband changes employment status, the wife changes employment status, or neither spouse changes. The models are linked by their dependence on the common unobserved random effects. Let $\mathrm{d}_{\mathrm{ijk \ell t}}=1$ if couple $\mathrm{k}$ 
moves from state $\mathrm{i}$ to state $\mathrm{j}$ after $\mathrm{t}$ periods in the $\ell^{\prime}$ th spell, $\mathrm{d}_{\mathrm{ijk} \ell \mathrm{t}}=0$ otherwise. The likelihood contribution of the t'th period in couple k's $\ell$ 'th spell, conditional on $\mu$ and $\delta$, is

$$
\mathrm{L}_{\mathrm{k} \ell t}\left(\mu_{\mathrm{k}}, \delta_{\mathrm{k} \ell}\right)=\sum_{\mathrm{i}=1}^{4} \sum_{\mathrm{j}=1, \mathrm{j} \neq \mathrm{j}(\mathrm{i})}^{4} \mathrm{~d}_{\mathrm{ijk} k \mathrm{t}} \mathrm{P}_{\mathrm{ijk} k \mathrm{t}}\left(\mu_{\mathrm{k}}, \delta_{\mathrm{k} \ell}\right)
$$

The likelihood contribution of couple k's $\ell$ 'th spell, conditional on $\mu$, is

$$
\mathrm{L}_{\mathrm{k} \ell}\left(\mu_{\mathrm{k}}\right)=\sum_{\mathrm{b}=1}^{\mathrm{B}} \pi_{2 \mathrm{~b}} \prod_{\mathrm{t}=1}^{\mathrm{D}_{\mathrm{k} \ell}} \mathrm{L}_{\mathrm{k} \ell \mathrm{t}}\left(\mu_{\mathrm{k}}, \delta_{\mathrm{bk} \ell}\right)
$$

where $\pi_{2 b}$ is the probability that the spell-specific error component takes on the value $\delta_{b}, b$ $=1, \ldots, \mathrm{B}$, and $\mathrm{D}_{\mathrm{k} \ell}$ is the duration (censored or otherwise) of couple k's $\ell^{\prime}$ th spell.

Suppose that the m'th endogenous regressor $Z_{k t m}(m=1, \ldots, M)$ is determined by

$$
\mathrm{Z}_{\mathrm{ktm}}=\mathrm{Q}_{\mathrm{kt}} \eta_{\mathrm{m}}+\rho_{3 \mathrm{~m}} \mu_{\mathrm{k}}+\zeta_{\mathrm{ktm}}
$$

where $Q_{k t}$ is a vector of exogenous explanatory variables, $\eta_{m}$ is a parameter vector, $\rho_{3 \mathrm{~m}}$ is a factor loading and $\zeta_{\mathrm{ktm}}$ is an i.i.d. error. Assume for convenience of exposition that $\zeta_{\mathrm{ktm}}$ is normally distributed and that $\mathrm{Z}_{\mathrm{ktm}}$ is continuous. Categorical variables can be handled easily as well. Let $\mathrm{P}_{\mathrm{mkt}}\left(\mu_{\mathrm{k}}, \sigma_{\mathrm{m}}\right)$ be the density function for $\mathrm{Z}_{\mathrm{ktm}}$, conditional on $\mu_{\mathrm{k}}$, where $\sigma_{\mathrm{m}}$ is the standard error of $\zeta_{\mathrm{ktm}}$.

Finally, suppose that there are F initial conditions, i.e. variables that have been determined in part by $\mu$, such as elapsed duration of the spell in progress when the couple is first observed, or total labor force experience and tenure of each member of the couple. An equation for the value of the $f^{\prime}$ th initial condition, $I_{k f}$, is

$$
\mathrm{I}_{\mathrm{kf}}=\mathrm{Q}_{\mathrm{kf}} \gamma_{\mathrm{f}}+\rho_{4 \mathrm{f}} \mu_{\mathrm{k}}+\lambda_{\mathrm{kf}}
$$


$Q_{k f}$ is a vector of exogenous time-invariant variables, $\gamma_{f}$ is a vector of parameters $\rho_{4 f}$ is a factor loading, and $\lambda_{\mathrm{kf}}$ is a disturbance. Again assume for simplicity that $\lambda_{\mathrm{kf}}$ is normally distributed and that $\mathrm{I}_{\mathrm{kf}}$ is continuous. Categorical variables can again be handled easily as well. Let $\mathrm{P}_{\mathrm{kf}}\left(\mu_{\mathrm{k}}, \sigma_{\mathrm{f}}\right)$ be the density function for $\mathrm{I}_{\mathrm{kf}}$, conditional on $\mu$, where $\sigma_{\mathrm{f}}$ is the standard error of $\lambda_{\mathrm{kf}}$.

The likelihood contribution for couple $\mathrm{k}$ is

$$
\mathrm{L}_{\mathrm{k}}=\sum_{\mathrm{a}=1}^{\mathrm{A}} \pi_{1 \mathrm{a}}\left[\prod_{1=1}^{\mathrm{G}_{\mathrm{k}}} \mathrm{L}_{\mathrm{kl}}\left(\mu_{\mathrm{ka}}\right) \prod_{\mathrm{f}=1}^{\mathrm{F}} \mathrm{P}_{\mathrm{kf}}\left(\mu_{\mathrm{ka}}, \sigma_{\mathrm{f}}\right) \prod_{\mathrm{m}=1}^{\mathrm{M}} \prod_{\tau=1}^{\mathrm{H}_{\mathrm{k}}} \mathrm{P}_{\mathrm{mk} \tau}\left(\mu_{\mathrm{ka}}, \sigma_{\mathrm{mk}}\right)\right]
$$

where $\pi_{1 \mathrm{a}}$ is the probability that the permanent factor takes on value $\mu_{\mathrm{a}}, \mathrm{a}=1, \ldots, \mathrm{A}, \mathrm{G}_{\mathrm{k}}$ is the number of spells observed for the k'th couple, $H_{k}$ is the number of years for which the $k$ 'th couple is observed, and $\tau$ is an index of the year of the observation. Finally, the sample loglikelihood function is

$$
\log \mathrm{L}=\sum_{\mathrm{k}=1}^{\mathrm{K}} \log \left(\mathrm{L}_{\mathrm{k}}\right)
$$

where $\mathrm{K}$ is the number of couples.

\section{Data and Descriptive Statistics}

We use data provided by the German Socioeconomic Panel (GSOEP), a nationally representative household panel study. Approximately 6,000 households in the western states of Germany (the former West Germany) have been interviewed annually since 1984. Households from the former East Germany were added to the sample in 1990 but are not included in the analysis here. We use data from the 1984 through 1994 interviews. We restrict our sample to married couples in which at least one spouse is in the age range of 50 to 69. Observations are censored upon dissolution of the marriage for any reason, or if data are missing on labor force status and on crucial explanatory variables, such as health, years of 
schooling, or work experience (see Table A-1 in the Appendix for a summary of censoring mechanisms). ${ }^{7}$ The estimation sample contains 1,553 couples with 2,928 spells observed for a total of 99,010 months, where as noted above a spell is defined by the employment status of both spouses.

The labor force participation behavior of the couples in our sample is summarized in Figures 1 and 2. At age 50, 95 percent of the husbands and 57 percent of the wives are employed. By age 65, the participation rates drop to 11 percent for the husbands and five percent for wives. Figure 2 describes the distribution of couples' joint labor force states by the age of the husband. At age 50 of the husband, it is more common to observe both spouses working than the husband working and the wife not employed. By age 57 the latter is more common. This is in part due to the trend toward increased employment of married women discussed earlier: more recent cohorts of wives, who are observed at younger ages in the data, are more likely to be employed, which causes a higher frequency of state 1 observations for younger couples. The incidence of state 3, in which only the wife is employed, peaks at age 62 of the husband, but is far lower than that of other states until age 64. State 4, with both spouses not working, is the most frequently observed state for couples with husbands older than 61 years.

The distribution of couple-months by employment state and the average monthly transition probabilities are described in Table 1. This summary of the data shows strong connections between the labor force behavior of spouses. The average monthly probability

${ }^{7}$ An individual appears in our sample as long as he or she remains married to the spouse to whom he or she was married in the first year of the survey (1984) or the first year of eligibility for the estimation sample (age 50). Modeling divorce is beyond the scope of the analysis. In some cases labor force status was missing for only one or two months. In order to avoid losing all the subsequent information from these cases we imputed labor force status for months with missing data if the number of consecutive months with missing data was three or less. Details of the imputation procedure and other data issues are described in an Appendix available upon request. 
that a husband stops working when the wife is employed $(1 \rightarrow 3)$ is 0.48 percent, while the probability that a husband stops working when the wife is not employed $(2 \rightarrow 4)$ is 0.93 percent. Similarly, wives of employed husbands leave employment $(1 \rightarrow 2)$ at an average monthly rate of 1.05 percent, and wives whose husbands are not employed leave employment $(3 \rightarrow 4)$ at an average monthly rate of 1.82 percent. The likelihood that a husband enters employment is 0.94 percent if his wife is employed $(3 \rightarrow 1)$ and 0.27 percent if she is not employed $(4 \rightarrow 2)$, and a similar pattern holds for the rate at which wives enter employment as a function of the husband's employment status ( 0.92 versus 0.21 percent).

Table 2 describes the distribution of the number of spells per couple. Close to sixty percent of the couples remain in just one spell for the entire period and another 30 percent switch states only one or two times. Nevertheless, Table 3 shows that with the exception of state 4 (both spouses not employed), the majority of spells is not censored.

The main finding from the above description of the data is that one member of an older married couple is much more likely to exit employment and much less likely to enter employment if his or her spouse is not employed than if the spouse is employed. This pattern, which we call coordination in transition behavior, is also observed in the United States (Blau, 1998), and Hurd (1990, p. 232) has offered a number of possible explanations for it. These include assortative mating on tastes or economic variables such as wages and retirement benefits, correlation in assets, and complementarity of husband's and wife's leisure in utility. The effect of changes in retirement regulations on this pattern may depend on the underlying cause of the pattern, so in the remainder of the paper we analyze which, if any, observed covariates can help account for this pattern.

We look for three types of patterns in the effects of covariates. First, we look for evidence of cross-spouse wage and retirement benefit effects. For example, if the wife's retirement benefit has a positive effect on her exit from employment and also has a positive 
effect on the likelihood that her husband exits employment or a negative effect on the likelihood that he enters employment, this would suggest that complementarity of leisure is part of the explanation for the pattern. Second, we explore cross-spouse effects of other covariates. For example, a man who is in poor health is more likely to exit employment than a healthy man, and if his poor health status also increases his wife's exit rate from employment then this could help account for the observed pattern of transition coordination. Finally, we look for differences in covariate effects by the spouse's employment status. For example, if the wife's poor health has a bigger positive effect on her employment exit rate when her husband is not employed than when he is employed, we would interpret this as evidence that assortative mating on unobservables or correlation across spouses in unobserved tastes play a role in explaining the pattern. We distinguish this case from complementarity of leisure because the latter has a very specific interpretation in models of family labor supply: the sign of the cross-spouse substitution effect of a change in the wage rate.

Descriptive statistics on the covariates are shown in Table 4. The covariates are derived from the annual surveys and do not vary by month within a year, except for spell duration and variables describing previous spells. Wages and benefits are likely to be endogenous to transition rates and wages (benefits) are unobserved for nonworkers (workers). We therefore estimated wage and benefit equations (separately for husbands and wives) on the subsamples with observed values, and used the estimates to predict wages and benefits for every sample member for every year. The predicted wage and benefit variables are estimates of the monthly wage that a person could earn were he or she to work in a given year, net of taxes, and the monthly public retirement benefit to which an individual would be entitled if he or she were to exit employment in that year, net of taxes. However, many women have not contributed to the public retirement system for enough years to be entitled to any benefit. Therefore, we also estimated an equation to explain whether a nonemployed married woman is 
receiving a retirement benefit, and we used the estimates to assign to each woman a probability of benefit entitlement. This was multiplied by the predicted benefit conditional on entitlement to yield an 'expected' benefit. The wage and benefit regressions are reported in the Appendix. This is a very simple approach to measuring the retirement incentives induced by the public retirement system, and may not capture all of the incentives caused by nonlinearities such as minimum required contribution years and spikes in pension accrual rates (BörschSupan and Schnabel, 1998). We follow this approach because accounting for features of the budget constraint induced by nonlinearities in the public pension system requires a structural approach to estimation that imposes unverifiable assumptions about preferences and expectations, which seems unwarranted in an exploratory study such as this. Our approach is most likely to adequately measure within-period incentives to retire or remain employed, but it may not capture the impact of current employment decisions on future incentives. ${ }^{8}$

The other variables included in the employment transition equations are age, health (whether the individual reports any chronic disease), years of schooling and dummies for specific academic and vocational degrees, years of work experience and job tenure, dummies for whether the individual's current or most recent occupation is blue-collar or white-collar (the omitted category is services), dummies for self-employment and public-sector employment (the omitted category is private-sector employee), ${ }^{9}$ dummies for foreign

${ }^{8}$ See Gustman and Steinmeier (1986), Stock and Wise (1990), Rust and Phelan (1997), and Blau and Gilleskie (1998) for dynamic, structural models of retirement behavior. Note that our approach does not directly measure unemployment or "pre-retirement" benefits, the latter consisting of either unemployment benefits with or without employer-supplements, or of disability retirement benefits. However, unemployment benefits are directly proportional to earnings and are therefore collinear with earnings, while disability benefits follow the same formula as regular retirement benefits and are therefore captured by the retirement benefit measure. The only benefits we are unable to measure are special payments from employers to laid off workers.

${ }^{9}$ The rationale for including the self-employment indicator is that the self-employed have more flexibility in their labor market transition decisions since they do not need to match an 
nationality and household ownership, household size, the national unemployment rate, and five regional dummies. In addition, several variables characterizing the current spell are incorporated, including the elapsed duration of the spell in progress when the couple is first observed, a quartic in duration of the spell in progress, a dummy for whether the current spell is the first spell observed for the couple, and dummies for whether the couple has ever previously occupied state $\mathrm{i}, \mathrm{i}=1, \ldots,{ }^{10}{ }^{10}$

\section{Results}

We estimated many different specifications of the employment transition models. These specifications included alternative sets of restrictions on the effects of wages and benefits, alternative polynomials on spell duration, alternative specifications of the effects of prior spells, alternative specifications of health, different characterizations of jobs, interactions between husband and wife characteristics, alternative numbers of discrete factors characterizing the unobserved heterogeneity distribution, alternative numbers of masspoints in the distribution of each factor, and alternative sets of equations for potentially endogenous initial conditions. A summary of the results of the specification tests is given in the Appendix. The model presented here is based on the results of specification tests, although in some cases we retain a relatively parsimonious version of a given variable despite rejection by the

employer's interests; also, they are not necessarily covered by the retirement insurance which is mandatory for blue and white collar workers. Public sector workers have a particularly low risk of layoff. In addition public sector workers have higher retirement benefits than is common in the private sector. Civil servants receive benefits according to an entirely different set of rules than individuals in the private sector, and non-civil servant employees in the public sector benefit from a significant pension in addition to the benefits from the mandatory retirement scheme.

${ }^{10}$ The only information available on private pensions is whether an individual is covered by one, and this was asked only of employees, so we do not use this variable. No information on financial assets is available. We use an indicator of home ownership as a crude proxy for assets. 
specification tests in order to avoid an excessive number of parameters. The results discussed below are from a model that includes one permanent discrete factor with three points of support, an equation to explain the initial employment state in which the couple is observed, unrestricted wage and benefit effects, and no interactions among husband and wife variables. Coefficient estimates and standard errors are given in the Appendix. The magnitudes of the coefficient estimates provide little information about the size of the covariate effects in a nonlinear model, so we do not discuss them. Instead, we used the estimates to simulate the impact of changes in each covariate on the transition rates. The simulations were computed for each couple-month observed in a given state and averaged over the couple-months in that state, allowing one covariate at a time to change while letting the others remain at their observed values. The simulation results are shown in Table 5. The first two rows of Table 5 show the actual transition rates and the rates predicted from the estimates using the actual values of all covariates. The model fits the average transition rates well except for overpredicting the rate at which husbands enter employment when the wife is not employed $(4 \rightarrow 2)$.

\section{Economic Variables}

With a few exceptions the effects of wages and benefits are in the expected direction: higher wages and lower benefits are associated with a stronger attachment to the labor force. The response to a given change in wages and benefits is generally larger for women than for men, consistent with the generally higher labor supply elasticities for women than men found in the literature. The own-wage effects on the exit probability from the joint employment state imply an elasticity of .50 for husbands and .88 for wives.

In addition, we find a number of sizeable cross-spouse effects. ${ }^{11}$ Having a high-wage

\footnotetext{
${ }^{11}$ This finding agrees with Zweimüller et al. (1996) and Allmendinger (1990) who find some evidence that wives respond to husbands' earnings in Austria and Germany, respectively.
} 
husband generally increases the labor force mobility of wives, making them both more likely to enter the labor force when they are out and to leave the labor force when they are in.

Husbands of high-earning wives have increased probabilities of exiting employment and reduced probabilities of entering employment. Having a wife who receives high retirement benefits increases the exit rate from employment for husbands whose wives are already retired and reduces their entry rate to employment. This is an interesting example of coordination in labor force behavior: the response of the husband's labor force exit probability to a change in the wife's wage rate is seven times larger if the wife is out of the labor force than if she is employed. The same pattern appears in the response of husbands to wives' expected retirement benefits: higher benefits for the wife are associated with increased labor force exit and reduced entry probabilities if the wife is not employed, but not if she is employed.

Finally, a number of the cross-spouse wage and benefit effects are asymmetric between the spouses. The effects of husbands' financial characteristics on exit probabilities out of state 2 are in the opposite direction to the effects of wives' characteristics on exit probabilities out of state 3. Higher retirement benefits of the husband increase the wife's reemployment probability and the husband's exit probability, but higher retirement benefits of a working wife reduce husbands' reemployment probabilities and the likelihood of wives' exit. Similarly, having a husband with high benefit claims induces wives to leave state 1 , but the effect of having a wife with high benefits has a small negative effect on husbands probabilities of leaving state 1.

\section{Effects of Health}

We specified models that included several different health indicators that are available in the dataset. However, the health measures provided in the GSOEP are not as varied and

The finding differs from Blau's (1998) results for the United States. 
detailed as those provided in other datasets, such as the U.S. Health and Retirement Study (HRS). For example, the GSOEP does not contain measures of functional limitations. We could not reject the hypotheses that a measure of subjective health satisfaction and the presence and degree of an officially recognized handicap had no impact on the transition rates. The only health variables included in the final specification are indicators for the presence of a chronic disease for each spouse. We recognize that chronic disease may not be the best indicator of health for purposes of explaining labor force behavior. ${ }^{12}$

Individuals with a chronic health condition are less likely to remain employed and more likely to exit the labor force. Wives are less likely to exit the labor force and more likely to enter the labor force if the husband has a chronic condition and is still working, and are more likely to exit and less likely to enter if the husband has left the labor force. The same pattern does not hold for men. Husbands are less likely to stop employment and less likely to reenter employment if the wife has a health condition, a response that is independent of the wife's labor force status.

\section{Transition Dynamics}

Almost sixty percent of couples in the sample never leave their first observed spell during the period of analysis, so it is of interest to compare behavior between first spells and subsequent spells. Being in the first spell reduces the exit rate from employment of husbands but increases the wife's exit rate. There is strong duration dependence in most of the transition rates, positive for exits from employment and negative for entry to employment. Another strong indicator of history dependence in couples' transition processes is the effect of having previously occupied a given state. The simulations show large increases in the probability of transiting into another state if the couple has been in that state in the past.

${ }^{12}$ See Blau, Gilleskie and Slusher (1997) and Bound et al. (1998) for detailed explorations of the effect of health on labor force behavior using data from the HRS. 


\section{Covariate Effects and Coordination of Transition Behavior}

The wage and benefit effects lend some support to the hypothesis of complementarity of leisure of the spouses, although not all of the results are consistent with the hypothesis. However, we find that the effects of several of the covariates on a given spouse's transition probabilities depend on the employment status of the other spouse. Examples of such effects are that (i) the husband's response to changes in the wife's earnings depend on the wife's labor force status; (ii) wives become less attached to the labor force in response to a husband's chronic disease if the husband is out of the labor force himself, but not if he is employed; and (iii) aging reduces the entry probabilities of wives about three times as much when the husband has already left the labor force than when he is still working. These effects suggest that spouses do coordinate their leisure in response to unobserved correlations in tastes.

\section{Conclusions}

The objective of this study was to describe and analyze the labor force transitions of older German married couples. The findings indicate a strong propensity among couples to spend leisure time together. Financial variables have asymmetric effects on spouses' labor force responses. We find strong impacts of health and age on transition behavior with systematic cross-spouse effects. Couples are more likely to move to an employment state if they have been in that state before. The evidence on coordination in labor force transitions is confirmed by the state dependence in spouses' response to changes in explanatory variables. This indicates that complementarity of leisure is an important determinant of the labor force behavior of older couples, confirming findings from other countries (e.g. Zweimüller et al., 1996; Blau, 1998; and Hurd, 1990).

The results have a number of policy implications. The findings call for consideration of the added dimension of joint couple behavior in the ongoing regulatory reforms of the 
retirement system in Germany and in other industrialized countries. They imply that current attempts to foster part-time employment are unlikely to be successful unless both spouses of a couple can stay employed. The findings indicate that increasing work incentives for women by increasing their minimum retirement age may have small effects given that financial variables have a smaller impact on behavior than the desire to share leisure time with an already retired spouse. The results also suggest that financial losses due to early retirement may not induce further labor force participation if spouses prefer to share time e.g. with a health impaired partner. 


\section{Appendix}

\section{$\underline{\text { Imputation Mechanism for Missing Monthly Labor Force Status Information }}$}

After coding monthly labor force status for each individual 651 spells with missing information were observed. Of these 651 spells with missing information, 505 were between spells that described the labor force status, 146 spells were either at the end of a person's observation period (91) or at the beginning (55). Imputations were performed for those of the 505 missing spells between informative spells, which had a duration of up to three months. If both informative spells, before and after the missing spell, were of the same type it was assumed that the person did not change labor force status in the intermediate period. If the person changed status between the last observed spell before (status B) the missing and the first observed spell after the missing (status A), we arbitrarily assigned the labor force status A for missing spells with a duration of one month, first B then A for missing spells with a duration of two months and the sequence B-A-A for missing spells with a duration of three months. By this mechanism 143 missing spells of duration 1, 74 missing spells of duration 2, and 66 missing spells of duration 3 months were imputed.

Observations with missing spells between informative spells that exceeded four months in duration were censored, as were observations with missing spells at the end of their observation period. Observations with missing spells at the beginning of their observation period were dropped from the sample. Table A-2 describes the frequency of adjustments relevant to the final sample, where 1 indicates no adjustments were made, 2 indicates that an observation was censored after the last informative spell, 3 indicates that observation was censored because of an intermediate missing spell longer than three months, and 4 indicates that a missing spell was imputed.

\section{$\underline{\text { Recoding of Couples' Joint State Transitions }}$}

In order to split up couples' joint transitions into two consecutive transitions 
intermediate states were introduced in the following manner:

Original transition in $\mathrm{t}$ :

New transition in $\mathrm{t}-1$ :

New transition in $\mathrm{t}$ :

$$
\begin{array}{llr}
1 \rightarrow 4 & 1 \rightarrow 2 & 2 \rightarrow 4 \\
2 \rightarrow 3 & 2 \rightarrow 4 & 4 \rightarrow 3 \\
3 \rightarrow 2 & 3 \rightarrow 4 & 4 \rightarrow 2 \\
4 \rightarrow 1 & 4 \rightarrow 2 & 2 \rightarrow 1
\end{array}
$$

The choice of intermediate states (state 2 for transition $1 \rightarrow 4$, and $4 \rightarrow 1$, and state 4 for transitions $2 \rightarrow 3$, and $3 \rightarrow 2$ ) was based on the probability with which couples in the sample choose the two potentially available intermediate states. For couples in state 1 a transition into state 2 occurred about twice as frequently as a transition into state 3 . Therefore state 2 was chosen as an intermediate state.

The procedure raised additional problems in the case of two couples who not only had joint transitions, but who also had changed their states in period $\mathrm{t}-1$, such that a recoding of the transition in period t-1 would have caused another joint transition, this time between periods $\mathrm{t}-2$ and period $\mathrm{t}-1$. The problem was solve by arbitrarily reassigning the couples' state in period $\mathrm{t}-1$. 


\section{References}

Allmendinger, Jutta, 1990, Der Übergang in den Ruhestand von Ehepaaren, Kölner Zeitschrift für Soziologie und Sozialpsychologie, special issue 31, 272-303.

Blau, David M., 1997, Social Security and the Labor Supply of Older Married Couples, Labour Economics 4, 373-418.

Blau, David M., 1998, Labor Force Dynamics of Older Married Couples, Journal of Labor Economics, 17 (3).

Blau, David M., and Donna B. Gilleskie, 1998, “A Dynamic Structural Model of Health Insurance and Retirement," manuscript, University of North Carolina at Chapel Hill.

Blau, David M., Donna B. Gilleskie, and Chuck Slusher, 1997, "The Effects of Health on Employment Transitions of Older Men," manuscript, University of North Carolina at Chapel Hill.

Bound, John, Michael Schoenbaum, Todd R. Stinebrickner, and Timothy Waidmann, 1998, "Measuring the Effects of Health on Retirement Behavior," manuscript, University of Michigan.

Börsch-Supan, Axel, 1997, The Consequences of Population Aging for Growth and Savings, in: L. Bovenberg and C. van Ewijk (eds.) Lecture Notes on Pensions and Aging, Oxford University Press.

Börsch-Supan, Axel and Schnabel, Reinhold, 1998, "Social Security and Retirement in Germany" in Gruber, Jonathan and David Wise, 1998, Social Security Programs and Retirement Around the World, Chicago, University of Chicago Press.

Bundesminister für Arbeit und Sozialordnung (ed.), 1996, Arbeits- und Sozialstatistik Hauptergebnisse 1996, Bonn / Germany.

Chiappori, Pierre-A., 1988, Rational Household Labor Supply, Econometrica 56(1), 63-89.

Chiappori, Pierre-A., 1992, Collective Labor Supply and Welfare, Journal of Political Economy 100(3), 437-467.

Giannelli, Gianna Claudia, 1996, Women's transitions in the Labour Market: A Competing Risks Analysis on German Panel Data, Journal of Population Economics 9(3), 287-300.

Gustman, A. and T. Steinmeier, 1986, "A Structural Retirement Model," Econometrica, 54, 555584.

Gustman, A. and T. Steinmeier, 1994, Retirement in a Family Context: A Structural Model for Husbands and Wives, mimeo.

Heidenreich, Hans-Joachim, 1991, Erste Ergebnisse des Mikrozensus April 1990, Wirtschaft und Statistik 11/1991, 715-719.

Heppt, Ehrenfried, 1995, Betriebliche Altersversorgung 1990 im früheren Bundesgebiet, Wirtschaft und Statistik 2, 155-165. 
Hurd, Michael D., 1990, The Joint Retirement Decisions of Husbands and Wives, in: David A. Wise (ed.), Issues in the Economics of Aging, Chicago, University of Chicago Press for the National Bureau of Economic Research, 231-258.

Jacobs, Klaus, Martin Kohli, and Martin Rein, 1991, Germany: The Diversity of Pathways, in: Kohli, Martin et al. (eds.), Time for Retirement, Cambridge University Press, 181-221.

Killingsworth, Mark R. and James J. Heckman, 1986, Female Labor Supply: A Survey, in: O. Ashenfelter and R. Layard, Handbook of Labor Economics, Elsevier Science Publishers Amsterdam, 103-204.

Kooreman, P. and A. Kapteyn, 1990, On the Empirical Implementation of some Game Theoretic Models of Household Labor Supply, Journal of Human Resources 25, 584-598.

Manser, Marilyn and Murray Brown, 1980, Marriage and Household Decision Making: A Bargaining Analysis, International Economic Review 21, 31-44.

McElroy, Marjorie, 1990, The Empirical Content of Nash-Bargained Household Behavior, Journal of Human Resources 25, 559-583.

McElroy, Marjorie and Mary Jean Horney, 1981, Nash-Bargained Household Decision: Toward a Generalization of the Theory of Demand, International Economic Review 22(2), 333-349.

Perrachi, Franco and Finis Welch, 1994, Trends in Labor Force Transitions of Older Men and Women, Journal of Labor Economics 12(2), 210-242.

Pischner, Rainer and Gert Wagner, 1992, Zwei Aspekte der Flexibilität beim Übergang vom Erwerbsleben in den Ruhestand, in: Hujer, R., R. Schneider and W. Zapf (eds.), Herausforderungen an den Wohlfahrtsstaat, 99-115.

Rust, John, and Christopher Phelan, 1997, "How Social Security and Medicare Affect Retirement Behavior in a World of Incomplete Markets," Econometrica, 65, 781-831.

Stock, James, and David Wise, 1990, "Pensions, the Option Value of Work, and Retirement," Econometrica, 58, 1151-1180.

van Soest, Arthur, 1995, Structural Models of Family Labor Supply, Journal of Human Resources 30(1), 63-88.

Wagner, Gert, 1991, Der Rentenzugang von Ehepaaren - Anmerkungen zur Empirie und Regulierung, in: Gather, C., U.Gerhard, K.Prinz, M.Veil (eds.), Frauen-Alterssicherung, 223-230.

Wagner, Gert, 1996, Gemeinsamer Rentenzugang - Ein neues Phänomen im Lebenslauf, in: Behrens, J. and W. Voges (eds.), Kritische Übergänge, Campus, Frankfurt, 323-348.

Zweimüller, Josef, Rudolf Winter-Ebmer, and Josef Falkinger, 1996, Retirement of Spouses and Social Security Reform, European Economic Review 40, 449-472. 


\begin{tabular}{|c|c|c|c|c|c|}
\hline \multirow[b]{2}{*}{ ORIGIN } & \multicolumn{4}{|c|}{ Transition into State } & \multirow[b]{2}{*}{ TOTAL } \\
\hline & 1 & 2 & 3 & 4 & \\
\hline \multirow[t]{2}{*}{ 1. Both employed } & 31,367 & 334 & 153 & - & 31,854 \\
\hline & $(98.47)$ & $(1.05)$ & $(0.48)$ & & $(100.00)$ \\
\hline \multirow[t]{2}{*}{ 2. Only husband } & 288 & 30,823 & - & 293 & 31,404 \\
\hline & $(0.92)$ & (98.15) & & $(0.93)$ & $(100.00)$ \\
\hline \multicolumn{6}{|l|}{ employed } \\
\hline \multirow[t]{2}{*}{ 3. Only wife } & 60 & - & 6,236 & 117 & 6,413 \\
\hline & $(0.94)$ & & (97.24) & $(1.82)$ & $(100.00)$ \\
\hline \multicolumn{6}{|l|}{ employed } \\
\hline \multirow[t]{2}{*}{ 4. Both OLF } & - & 80 & 61 & 29,198 & 29,339 \\
\hline & & $(0.27)$ & $(0.21)$ & $(99,52)$ & $(100.00)$ \\
\hline TOTAL & & & & & 99,010 \\
\hline
\end{tabular}

Table 2 Number of Spells Observed by Couple

\begin{tabular}{l|rrrrrrrr|r}
\hline Number of spells & 1 & 2 & 3 & 4 & 5 & $6-10$ & $11-20$ & $>20$ & Total \\
\hline Number of couples & 915 & 353 & 138 & 62 & 34 & 37 & 13 & 1 & 1,553 \\
Fraction of couples & 58.92 & 22.73 & 8.89 & 3.99 & 2.19 & 2.38 & 0.84 & 0.06 & 100 \\
\hline
\end{tabular}

Table 3 Distribution of Spells, Spell Duration and Transitions Across States

\begin{tabular}{|c|c|c|c|c|c|c|c|}
\hline \multirow[t]{2}{*}{ State } & & \multicolumn{5}{|c|}{ Transition into } & \multirow{2}{*}{$\begin{array}{r}\text { Average } \\
\text { Durat } \\
\text { ion } \\
\text { (in months) }\end{array}$} \\
\hline & $\begin{array}{c}\text { Numbe } \% \\
\text { r }\end{array}$ & 1 & 2 & 3 & 4 & Censored & \\
\hline 1 & 93331.9 & - & .3569 & .1608 & - & .4823 & 34.1 \\
\hline 2 & 100234.2 & .2854 & - & - & .2894 & .4251 & 31.3 \\
\hline 3 & 29810.2 & .2013 & - & - & .3893 & .4094 & 21.5 \\
\hline 4 & 69523.7 & - & .1137 & .0878 & - & .7986 & 42.2 \\
\hline
\end{tabular}




\begin{tabular}{|c|c|c|}
\hline Variable Description & Mean & Std. Dev. \\
\hline \multicolumn{3}{|l|}{ Demographic Information } \\
\hline Number of household members & 2.884 & 1.113 \\
\hline Couple owns home & 0.601 & 0.490 \\
\hline Duration of couples' first observed ongoing spell (in years) & 13.557 & 12.087 \\
\hline Duration of couples' first observed ongoing spell missing & 0.012 & 0.111 \\
\hline Couple in first observed spell & 0.53 & \\
\hline Duration of current spell (months) & 33.8 & \\
\hline Couple ever previously in state 1 & 0.60 & \\
\hline Couple ever previously in state 2 & 0.58 & \\
\hline Couple ever previously in state 3 & 0.21 & \\
\hline Couple ever previously in state 4 & 0.20 & \\
\hline Age of wife & 55.160 & 7.247 \\
\hline Age of husband & 58.568 & 7.045 \\
\hline Couple is from foreign subsample & 0.102 & 0.302 \\
\hline Survey year & 1988.225 & 2.861 \\
\hline National annual unemployment rate & 8.194 & 1.018 \\
\hline State couple lives in: Schleswig-Holstein & 0.029 & 0.168 \\
\hline State couple lives in: Northrhine-Westfalia (NRW) & 0.255 & 0.436 \\
\hline Region couple lives in: North & 0.171 & 0.376 \\
\hline Region couple lives in: Central & 0.195 & 0.397 \\
\hline Region couple lives in: South & 0.349 & 0.477 \\
\hline \multicolumn{3}{|l|}{ Human Capital and Education Variables } \\
\hline Husband's years of schooling & 11.248 & 2.441 \\
\hline Wife's years of schooling & 10.206 & 1.822 \\
\hline Husband's schooling degree: Realschule & 0.129 & 0.335 \\
\hline Husband's schooling degree: Abitur & 0.108 & 0.311 \\
\hline Husband's schooling degree: Fachhochschulreife & 0.094 & 0.292 \\
\hline Husbands'schooling degree: None & 0.054 & 0.225 \\
\hline Wife's schooling degree: Realschule & 0.162 & 0.369 \\
\hline Wife's schooling degree: Abitur & 0.035 & 0.183 \\
\hline Wife's schooling degree: Fachhochschulreife & 0.070 & 0.256 \\
\hline Wife's schooling degree: None & 0.057 & 0.232 \\
\hline Husband's vocational degree: Apprenticeship & 0.454 & 0.498 \\
\hline Husband's vocational degree: other voc. training & 0.201 & 0.401 \\
\hline Husband's vocational degree: university degree & 0.082 & 0.275 \\
\hline Wife's vocational degree: Apprenticeship & 0.314 & 0.464 \\
\hline
\end{tabular}


Wife's vocational degree: other voc. training

$0.142 \quad 0.349$

Wife's vocational degree: university degree

$0.032 \quad 0.176$

Wife's tenure on current job

$5.109 \quad 8.897$

Husband's tenure on current job

13.851

13.651

Wife's labor force experience

$15.193 \quad 13.016$

Husband's labor force experience

40.053

8.483

Couples' financial and occupational situation

Predicted probability that wife will receive benefits

$0.221 \quad 0.249$

Wife's predicted retirement benefits (in 1985 DM per month)

$544.574 \quad 257.767$

Husband's predicted retirement benefits (in 1985 DM per month)

$1550.761 \quad 398.791$

Wife's predicted net labor income (in 1985 DM per month)

$1303.694 \quad 365.009$

Husband's predicted net labor income (in 1985 DM per month)

$2789.304 \quad 735.338$

Wife in blue collar occupation

$0.175 \quad 0.380$

Wife in white collar occupation

$0.203 \quad 0.402$

Wife self-employed

$0.055 \quad 0.229$

Wife employed in public sector

$0.103 \quad 0.304$

Husband in blue collar occupation

$0.291 \quad 0.454$

Husband in white collar occupation

$0.216 \quad 0.411$

Husband self-employed

$0.091 \quad 0.287$

Husband employed in public sector

$0.164 \quad 0.370$

\section{Couples'Health}

Wife has chronic disease

$0.417 \quad 0.486$

Husband has chronic disease

$0.467 \quad 0.493$

Sample Size

99.010 
Table 5 Simulated Effects of the Covariates on Transition Probabilities: Absolute Differences in Simulated Transition Rates (Percentage Effects)

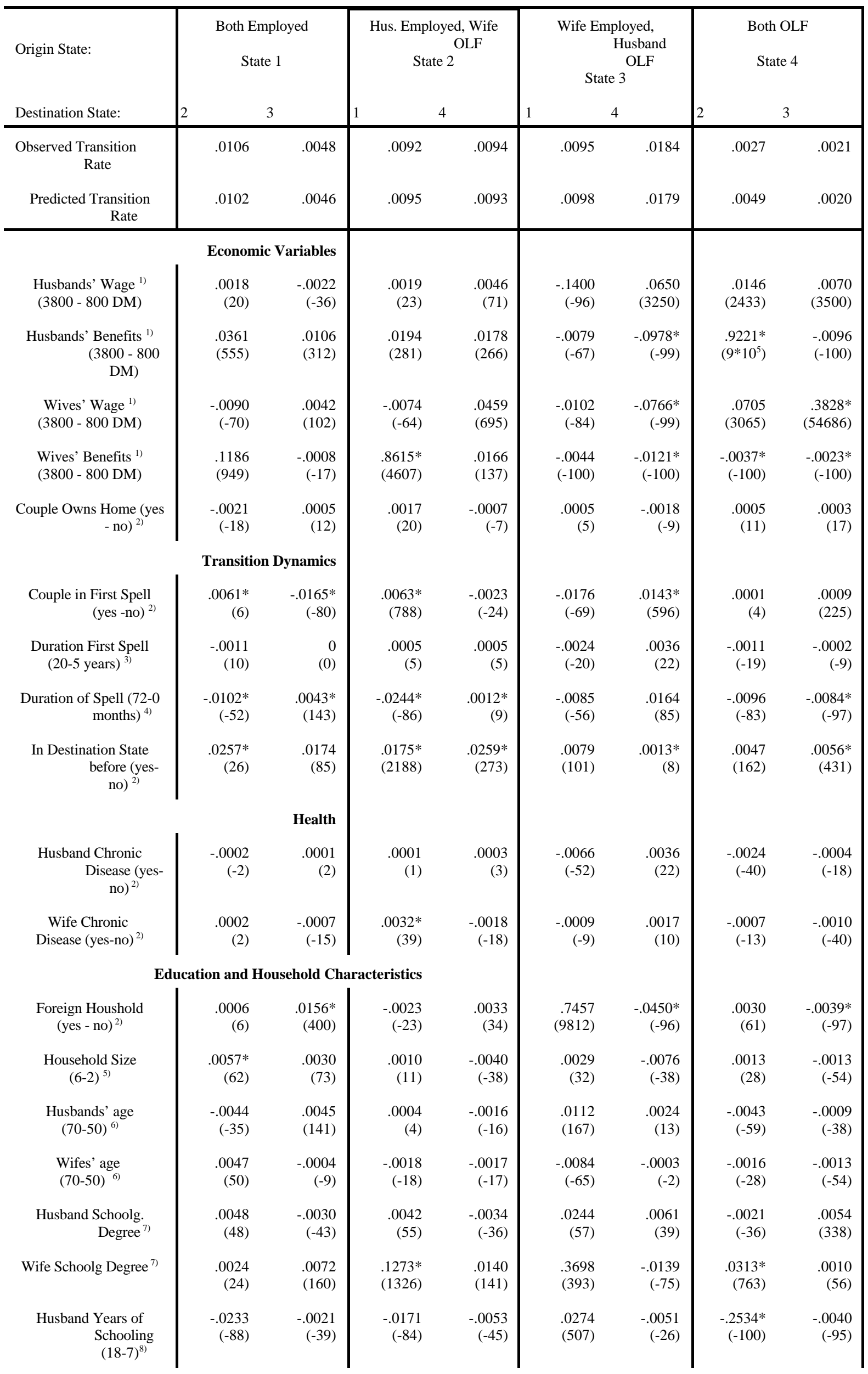




\begin{tabular}{|c|c|c|c|c|c|c|c|c|}
\hline $\begin{array}{l}\text { Wife Years of Schooling } \\
\qquad(18-7)^{8)}\end{array}$ & $\begin{array}{r}-.0071 \\
(-55)\end{array}$ & $\begin{array}{r}-.0057 \\
(-79)\end{array}$ & $\begin{array}{r}-.0582^{*} \\
(-99)\end{array}$ & $\begin{array}{r}-.0199 \\
(-93)\end{array}$ & $\begin{array}{l}-.12235 \\
(-100)\end{array}$ & $1.5^{*} 10^{4}$ & $\begin{array}{r}.0024 \\
(56)\end{array}$ & $\begin{array}{r}.0015 \\
(88)\end{array}$ \\
\hline Husband Public Sector ${ }^{9)}$ & $\begin{array}{r}.0024 \\
(25)\end{array}$ & $\begin{array}{r}-.0040 \\
(-53)\end{array}$ & $\begin{array}{r}.0021 \\
(20)\end{array}$ & $\begin{array}{r}-.0035 \\
(-32)\end{array}$ & $\begin{array}{l}.0113 \\
(257)\end{array}$ & $\begin{array}{r}.0040 \\
(22)\end{array}$ & $\begin{array}{r}-.0025 \\
(-42)\end{array}$ & $\begin{array}{r}-.0010 \\
(-71)\end{array}$ \\
\hline Wife Public Sector ${ }^{9)}$ & $\begin{array}{r}-.0001 \\
(-1)\end{array}$ & $\begin{array}{r}-.0002 \\
(-4)\end{array}$ & $\begin{array}{r}-.0035 \\
(-96)\end{array}$ & $\begin{array}{r}.0022 \\
(25)\end{array}$ & $\begin{array}{l}-.0068 \\
(-100)\end{array}$ & $\begin{array}{r}.0161 \\
(82)\end{array}$ & $\begin{array}{r}-.0054 \\
(-71)\end{array}$ & $\begin{array}{l}.0017 \\
(100)\end{array}$ \\
\hline \multicolumn{9}{|c|}{ Aggregate Time and Unemployment Effects } \\
\hline Year $(1993-84)^{10)}$ & $\begin{array}{r}.0049 \\
(60)\end{array}$ & $\begin{array}{l}.0034 \\
(100)\end{array}$ & $\begin{array}{r}-.0042 \\
(-36)\end{array}$ & $\begin{array}{r}.0048 \\
(65)\end{array}$ & $\begin{array}{r}.0031 \\
(36)\end{array}$ & $\begin{array}{r}-.0085 \\
(-37)\end{array}$ & $\begin{array}{r}.0015 \\
(35)\end{array}$ & $\begin{array}{r}.0007 \\
(29)\end{array}$ \\
\hline $\begin{array}{l}\text { Unemployment Rate } \\
\qquad(9.3-6.3)^{11)}\end{array}$ & $\begin{array}{r}.0019 \\
(21)\end{array}$ & $\begin{array}{r}.0025 \\
(78)\end{array}$ & $\begin{array}{r}-.0041 \\
(-33)\end{array}$ & $\begin{array}{r}.0030 \\
(39)\end{array}$ & $\begin{array}{l}.0064 \\
(107)\end{array}$ & $\begin{array}{r}.0011 \\
(6)\end{array}$ & $\begin{array}{r}-.0025 \\
(-38)\end{array}$ & $\begin{array}{r}-.0008 \\
(-32)\end{array}$ \\
\hline
\end{tabular}

Notes:

0) Asterisks indicate statistical significance at the 5 percent level for at least one of the estimated coefficients underlying the simulation.

1) The first line subtracts the probability of a transition at income DM 800 from that at income DM 3,800 . The figure in parentheses relates that difference to the transition probability if the income amounts to DM 3,800 and describes the percentage change in the transition probability.

2) The first line subtracts the probability of a transition if 'no' from the transition probability if 'yes.' The second line describes the change relative to "no.'

3) The first line subtracts the probability of a transition at a spell length of 5 years from that of a transition at a spell length of 20 years. The relative difference in line two is based on the 5 year spell.

4) The first line subtracts the transition probability at spell length of 72 months from that at a spell length of 0 months, the second line relates this difference to the probability at duration zero months.

5) The first line subtracts the transition probability for households with 2 members from that for households with 6 members, the relative difference is calculated based on 2 person housholds.

6) The first line subtracts the transition probability for those aged 50 from that for those aged 70 , and the second relates this difference to the transition probabilities for couples with a spouse aged 50 .

7) The first line subtracts the transition probability for Hauptschuldegree from that for Abitur degree, the relative difference is calculated based on Hauptschuldegree.

8) The first line subtracts the transition probability for 7 years of schooling from that for 18 years of schooling, the relative difference is calculated based on 7 years of schooling.

9) The first line subtracts the transition probability for a blue collar worker from that for a public sector employee. The relative difference is calculated relative to the blue collar worker's transition probability.

10) The first line subtracts the transition probability in 1984 from that in 1993, and the second line relates this difference to the probability in 1984 .

11) The first line subtracts the transition probability under 6.3 percent unemployment from that at 9.3 percent unemployment, the relative difference is calculated based on 6.3 percent unemployment. 
Figure 1 Probability of Labor Force Participation by Age

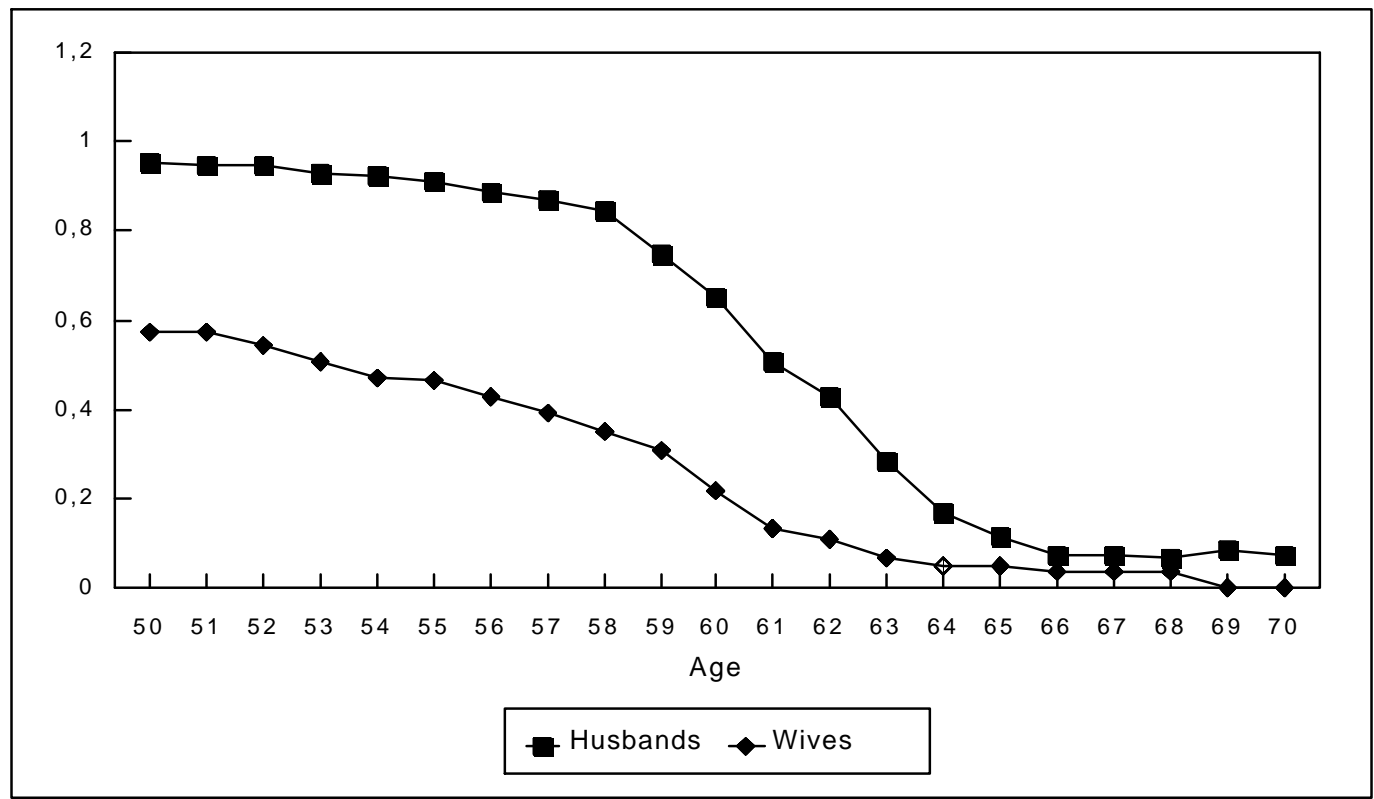

Figure 2 Labor Force Status of Couples by Husbands' Age

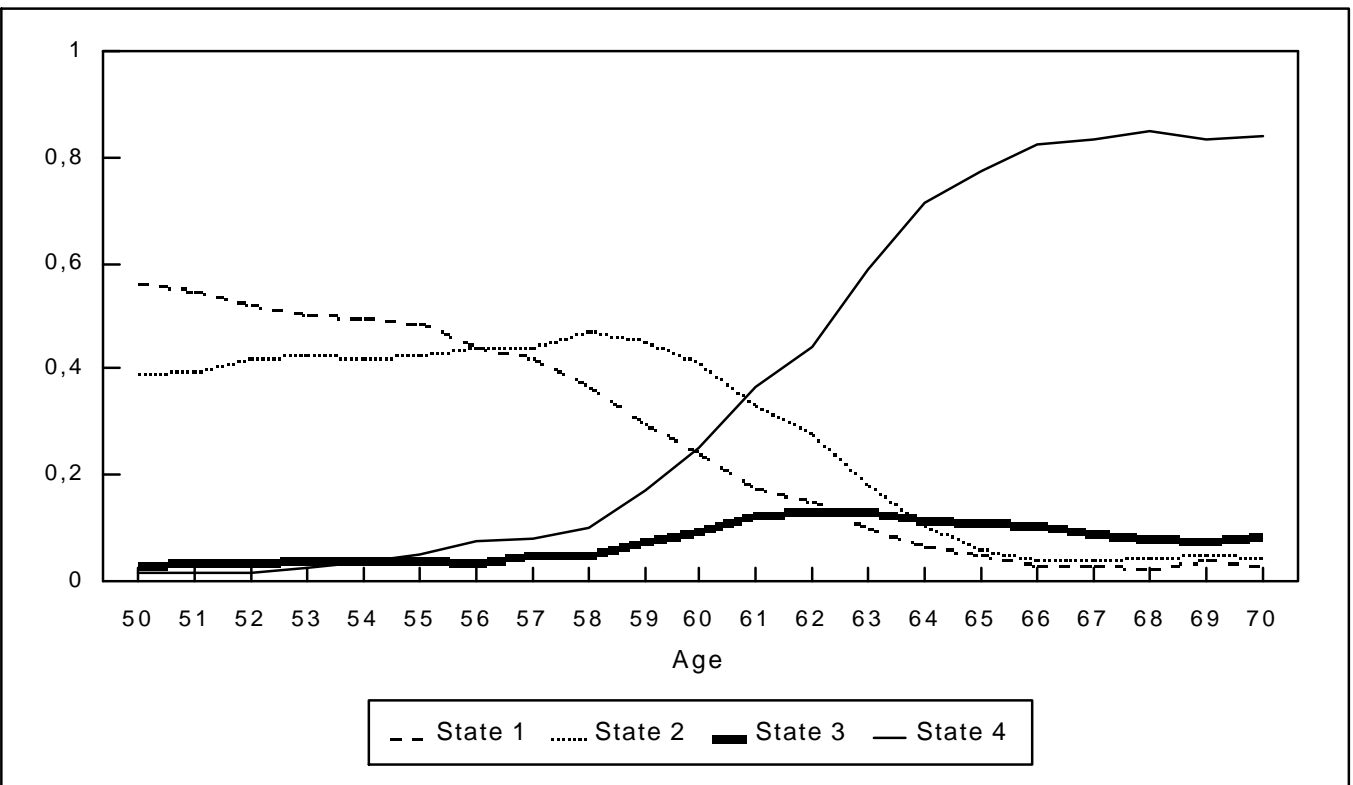

Note:

State 1 indicates that both spouses are employed, in state 2 only the husband, in state 3 only the wife is employed, in state 4 neither spouse is employed. 
Table A-1 Observations Lost Due to Censoring

\begin{tabular}{c|c|cccc}
\hline Year & $\begin{array}{l}\text { Couples } \\
\text { originally } \\
\text { observed }\end{array}$ & $\begin{array}{c}\text { Missing } \\
\text { explanatory } \\
\text { variable }\end{array}$ & $\begin{array}{c}\text { Marital status } \\
\text { indicators do not } \\
\text { match }\end{array}$ & $\begin{array}{c}\text { Missing } \\
\text { dependent } \\
\text { variable }\end{array}$ & $\begin{array}{c}\text { Reach last year } \\
\text { of data }\end{array}$ \\
\hline 1984 & 972 & 15 & 39 & 618 & 300 \\
1985 & 79 & 2 & 5 & 39 & 33 \\
1986 & 71 & 0 & 6 & 32 & 33 \\
1987 & 76 & 1 & 3 & 28 & 44 \\
1988 & 84 & 0 & 3 & 25 & 56 \\
1989 & 68 & 0 & 4 & 11 & 53 \\
1990 & 62 & 0 & 2 & 9 & 51 \\
1991 & 44 & 0 & 1 & 9 & 34 \\
1992 & 52 & 0 & 0 & 6 & 46 \\
1993 & 45 & 0 & 0 & 0 & 45 \\
\hline Total & 1553 & 18 & 63 & 777 & $(44.75)$ \\
\hline
\end{tabular}


Table A.2 Observations Adjusted for Missing Data

(i) One Observation for Each Couple-Month (row percentages in parentheses)

\begin{tabular}{c|rrrr|r}
\hline Wife's status & \multicolumn{3}{|c|}{ Husband's Status } & Total \\
& 1 & 2 & 3 & 4 & \\
\hline 1 & 81,900 & 2,090 & 3,426 & 4,710 & 92,126 \\
No adjustments & $(82.72)$ & $(2.11)$ & $(3.46)$ & $(4.76)$ & $(93.05)$ \\
2 & 748 & - & 2 & - & 750 \\
Censored at last spell & $(0.76)$ & & $(0.00)$ & & $(0.76)$ \\
3 & 1,042 & 36 & 341 & 6 & 1,425 \\
Censored at interm. spell & $(1.05)$ & $(0.04)$ & $(0.34)$ & $(0.01)$ & $(1.44)$ \\
4 & 3,720 & 120 & 137 & 732 & 4,709 \\
Imputation & $(3.76)$ & $(0.12)$ & $(0.14)$ & $(0.74)$ & $(4.76)$ \\
\hline Total & 87,410 & 2,246 & 3,906 & 5,448 & 99,010 \\
& $(88.29)$ & $(2.27)$ & $(3.94)$ & $(5.51)$ & $(100.00)$ \\
\hline
\end{tabular}

(ii)

One Observation for Each Couple (row percentages in parentheses)

\begin{tabular}{c|rrrr|r}
\hline Wife's status & \multicolumn{3}{|c|}{ Husband's Status } & Total \\
& 1 & 2 & 3 & 4 & \\
\hline 1 & 1,274 & 38 & 68 & 60 & 1,440 \\
No adjustments & $(82.03)$ & $(2.45)$ & $(4.38)$ & $(3.86)$ & $(92.72)$ \\
2 & 14 & - & 1 & - & 15 \\
Censored at last spell & $(0.90)$ & & $(0.06)$ & & $(0.96)$ \\
3 & 25 & 1 & 8 & 1 & 35 \\
Censored at interm. spell & $(1.61)$ & $(0.06)$ & $(0.52)$ & $(0.06)$ & $(2.25)$ \\
4 & 44 & 3 & 4 & 12 & 63 \\
Imputation & $(2.83)$ & $(0.19)$ & $(0.26)$ & $(0.77)$ & $(4.05)$ \\
\hline Total & 1,357 & 42 & 81 & 73 & 1,553 \\
& $(87.37)$ & $(2.70)$ & $(5.22)$ & $(4.69)$ & $(100,00)$ \\
\hline
\end{tabular}


Table A-3

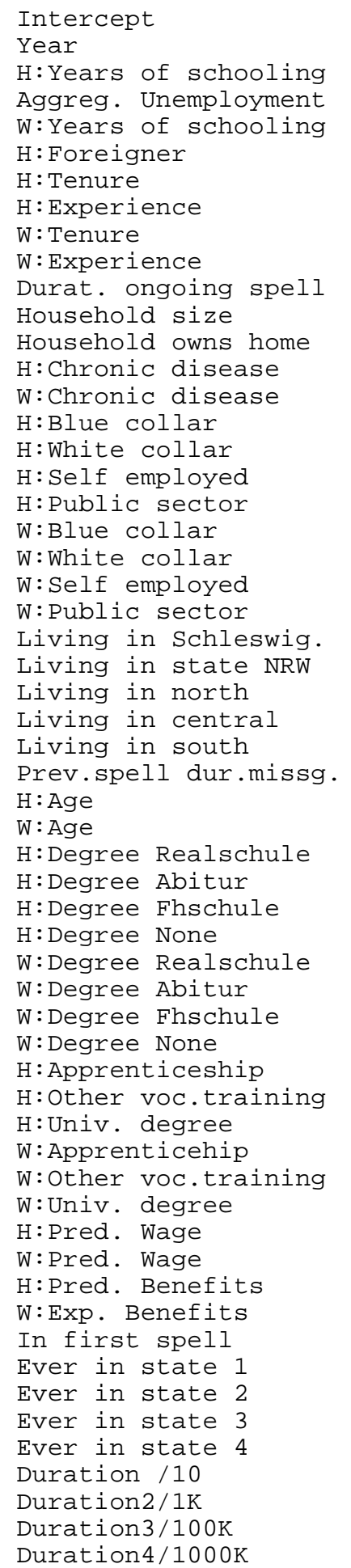

\section{Estimation Results}

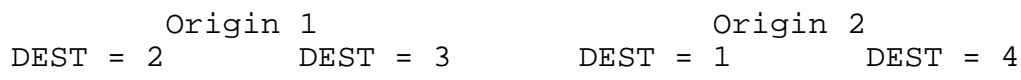

$-4.3398(1.1788)-7.8609(1.3868)$ $.0546(.0376) \quad .0805(.0525)$

$-.2008(.1675)-.0480(.2526)$ $.0665(.0969) \quad .1938(.1348)$

$-.0743(.1564)-.1434(.1935)$

$.0743(.6665) 1.6480(.8328)$

$-.0012(.0106) \quad .0078(.0197)$

$-.0099(.0084)-.0136(.0138)$

$.0144(.0139)-.0057(.0198)$

$.0015(.0215)-.0062(.0247)$

$-.0073(.0055)-.0005(.0083)$

$.1260(.0629) \quad .1430(.0963)$

$-.2041(.1512) \quad .1129(.2252)$

$-.0227(.1308) \quad .0187(.1942)$

$.0164(.1486)-.1572(.2125)$

$-.1319(.2452) .7618(.4802)$

$-.2577(.2552) \quad .2723(.5054)$

$-.0782(.4126)-.6750(.8789)$

$.0846(.1859) \quad .0031(.3508)$

$-.1781(.2315) \quad .0922(.4454)$

$-.0912(.2597) .1494(.5045)$ $.2575(.4002)-.3403(.9533)$

$-.1897(.2396) \quad .0529(.7537)$

$.3688(.5624) .3838(.9427)$

$-.1034(.4589) \quad .1894(.5483)$ $.1758(.4788) \quad .6078(.5671)$

$-.2301(.4793) \quad .1984(.5693)$

$-.2648(.4599) \quad .4483(.5360)$

$-.4084(.8834)-.1159(1.0008)$

$-.0220(.0167) \quad .0450(.0225)$

$.0212(.0145)-.0034(.0198)$

$.0020(.2429) .0667(.3842)$

$.4088(.7333)-.5778(.9323)$

$.3862(.5965)-.7494(.7528)$

$-.5294(.7158)-1.7392(.8602)$

$.1907(.2221) .4491(.3470)$

$.2272(.8071) .9921(1.0033)$

$-.0331(.6901)-.4287(.8592)$

$-.6580(.6521)-.1883(.8411)$

$.0585(.2349)-.5604(.3976)$

$.1715(.2915)-.1277(.4687)$

$.1997(.3052)-1.0473(.8562)$

$.1712(.2380) \quad .9224(.3936)$

$-.0096(.3316) \quad .2650(.7024)$

$.5862(.4946) 1.3155(.8616)$

$.0592(.4362)-.1487(.7564)$

$-.4085(.9357) .2387(.9976)$

$.6639(.8625) .5031(.9914)$

$.8743(.9464)-.0072(1.0028)$

$1.9643(.6690)-1.6763(.6871)$

$-.3435(.1771)-.6686(.5640)$

$3.3352(.6604)-1.3152(.6284)$

$1.0231(.5741) .6571(.6823)$

$-.1017(.6222) 1.0513(.9644)$

$-.9063(.1895) .3584(.2841)$

$2.7783(.7411)-1.7785(.6921)$

$-3.4121(1.0729) \quad 3.0306(.8610)$

$1.5240(.5042)-1.4094(.4661)$
$.4347(1.0854)-2.6855(1.0351)$

$-.0515(.0422) \quad .0565(.0415)$

$-.1813(.1902)-.0562(.1845)$

$-.1437(.1088) .1109(.1052)$

$-.5433(.1532)-.2589(.1614)$

$-.2787(.7095)-.4320(.7394)$

$-.0033(.0128)-.0043(.0122)$

$.0069(.0100)-.0095(.0084)$

$-.0035(.0158)-.0011(.0159)$

$-.0232(.0226)-.0332(.0227)$

$.0039(.0058) \quad .0033(.0059)$

$.0256(.0736)-.1239(.0729)$

$.1855(.1764)-.0712(.1493)$

$.0118(.1471) .0302(.1382)$

$.3415(.1579)-.1917(.1581)$

$.0990(.2416) .0759(.2923)$

$-.1012(.2520)-.0175(.3034)$

$-.4481(.4355)-.4825(.5183)$

$.3003(.2167)-.3218(.2401)$

$-.1053(.2314)-.0979(.2693)$

$-.4936(.2601)-.2259(.2740)$

$.5261(.3710) .3776(.4085)$

$-.5811(.3197) .1303(.2481)$

$.2859(.4861) .2079(.5137)$

$1.1821(.4926)-.0030(.4972)$

$1.1212(.5154) .1112(.5161)$

$1.2865(.5180) .0821(.5050)$

$1.3334(.5113) .2490(.5001)$

$.2948(.8058)-.7841(.9977)$

$.0022(.0192)-.0087(.0176)$

$-.0106(.0167)-.0093(.0146)$

$.3785(.2893) .0912(.2512)$

$.4741(.7716)-.4503(.8327)$

$.8522(.6138) .3912(.5980)$

$1.3511(.6858)-.0693(.8368)$

$.6703(.2522)-.2431(.2422)$

$3.2071(.7996) 1.0611(.9182)$

$.1858(.7496)-.1061(.7101)$

$-1.7384(.6245)-.9563(.8827)$

$.2793(.2825)-.1863(.2453)$

$.2896(.3774) \quad .0758(.3340)$

$.6939(.3361) .0957(.3266)$

$.4744(.2554) .1932(.2324)$

$.3685(.3527) .4108(.3188)$

$.4028(.5292)-.2621(.6988)$

$.0763(.4911) .1839(.4461)$

$-.3525(.9507) \quad .7224(.9579)$

$.4942(.8813) .4550(.9042)$

$2.5491(.9798) 1.0364(.9680)$

$2.2329(.7155)-.2749(.5403)$

$3.2544(.7178)-.0669(.5272)$

$.0599(.2112) .0053(.2148)$

$1.3147(.6972) .3099(.6016)$

$-1.0171(.6170) 1.3534(.5390)$

$-1.3922(.2348)-.8768(.1766)$

$4.0710(.7978) 2.8138(.6142)$

$-5.0315(1.1815)-3.0236(.8463)$

$2.0970(.6558) 1.1443(.3953)$ 
Intercept

Year

H:Years of schooling

Aggreg. Unemployment

W: Years of schooling

$\mathrm{H}$ : Foreigner

$\mathrm{H}$ : Tenure

$\mathrm{H}$ : Experience

W: Tenure

W : Experience

Durat. ongoing spell

Household size

Household owns home

H:Chronic disease

W:Chronic disease

$\mathrm{H}$ :Blue collar

$\mathrm{H}$ :White collar

$\mathrm{H}$ : Self employed

$\mathrm{H}$ :Public sector

W:Blue collar

W: White collar

W:Self employed

W:Public sector

Living in Berlin

Living in state NRW

Living in north

Living in central

Living in south

Prev spell dur.miss

$\mathrm{H}$ : Age

$\mathrm{W}:$ Age

H:Degree Realschule

$\mathrm{H}$ : Degree Abitur

H:Degree Fhschule

$\mathrm{H}$ : Degree None

W:Degree Realschule

W: Degree Abitur

W:Degree Fhschule

$W$ : Degree None

$\mathrm{H}$ : Apprenticehip

$\mathrm{H}$ : other voc.traing.

$\mathrm{H}$ : Univ. degree

W:Apprenticeship

W: other voc.traing.

W: Univ. degree

$\mathrm{H}$ : Pred. Wage

W: Pred. Wage

$\mathrm{H}$ : Pred. Benefits

W: Exp. Benefits

In first spell

Ever in state 1

Ever in state 2

Ever in state 3

Ever in state 4

Duration /10

Duration $2 / 1 \mathrm{~K}$

Duration3/100K

Duration $4 / 1000 \mathrm{~K}$
$\operatorname{DEST}=1^{\text {Origin } 3} \operatorname{DEST}=4 \quad \operatorname{DEST}=2^{\text {Origin } 4} \operatorname{DEST}=3$

$.6580(23.4687)-19.8152(28.7984) \quad 2.2167(2.0340)-13.0131(40.0553)$

$.0434(.1245)-.0545(.0730) \quad .0455(.0797) \quad .0454(.0823)$

$.2235(.3525)-.0252(.2661)-1.4515(.3738)-.3602(.4379)$

$.3092(.3173) \quad .0243(.1749)-.2152(.2069)-.1312(.2118)$

$\begin{array}{llllll}-1.0737(.7722) & .6225(\quad .1966) & .0569(\quad .2087) & .0621 & .06362)\end{array}$

$15.4170(41.5927)-3.1450(.8501) \quad .6479(1.3737)-3.8526(1.4235)$

$.0416(.0338)-.0493(.0197)-.0126(.0220)-.0124(.0227)$

$\begin{array}{rrrrr}.0159(.0301) & .0572(.0213) & .0377(.0194) & .0361( & .0221)\end{array}$

$.0308(.0474) \quad .0622(.0243)-.0072(.0267)-.0181(.0284)$

$.0131(.0633) \quad .0744(.0271) \quad .0499(.0307) \quad .0176(.0336)$

$-.0197(.0150) \quad .0101(.0108)-.0195(.0110)-.0091(.0131)$

$.0883(.2400)-.1231(.1252) \quad .0862(.1708)-.1872(.2004)$

$.0727(.6392)-.1059(.2932) \quad .1363(.4215) \quad .1470(.4747)$

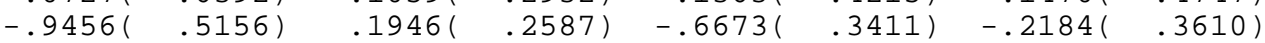

$\begin{array}{llllll}-.1112(.5650) & .0972(.2768) & -.2125(.3974) & -.5058(.3583)\end{array}$

$\begin{array}{llllll}-.7549(.7633) & -.0022(.4382) & .2125(.5636) & -.4179( & .6858)\end{array}$

$1.1200(.7218) \quad .3859(.5753) \quad .0550(.5997)-.6312(.6607)$

$3.0913(.8394)-.3728(.7930)-.4350(.8416)-.9482(\quad .9108)$

$.8955(.7261)-.2491(.5487)-.5163(.6545)-1.0170(.6956)$

$\begin{array}{lllll}-.8545(. .7439) & -.0391(. .4814) & .5743(.5059) & .0688( & .7674)\end{array}$

$\begin{array}{llllll}-.5649(.8291) & -.7723(.5028) & -.4811(.6522) & .0836(.6088)\end{array}$

$\begin{array}{llll}-.7509(.9729) & .1906(.7412) & .4422(.8589) & 1.3014(.8043)\end{array}$

$-18.9162(64.9148) \quad .5960(.5304)-1.0076(.6110) \quad .7543(.7401)$

$-1.3719(1.1229) \quad 1.6144(.8072)-2.4803(.9841) \quad 1.2798(.8418)$

$10.1642(19.4816) \quad 11.2700(28.6604)-2.5541(.8528) \quad 12.3493(41.0496)$

$10.6410(19.4904) \quad 10.8393(28.6695)-.5883(.6986) 11.7259(41.0286)$

$9.1611(19.4959) \quad 11.2634(28.6614)-2.5203(.8454) 12.2532(41.0335)$

$10.9595(19.4864) \quad 10.9794(28.6668)-.4787(.6746) 12.4711(41.0454)$

$-16.1659(41.6789)-.4203(1.0219)-20.8892(59.3740)-15.1207(45.1737)$

$.0647(.0555)-.0061(.0320)-.0597(.0419)-.0266(\quad .0449)$

$\begin{array}{llllll}-.0670(.0487) & -.0015(.0291) & -.0412(.0344) & -.0429( & .0357)\end{array}$

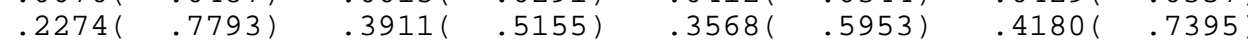

$2.1299\left(\begin{array}{llll}2.5317) & .3754(.9097) & -.5339(1.1271) & 1.3488(1.0308)\end{array}\right.$

$3.3972(1.9285)-.0483(.7859)-2.0902(\quad .9103) \quad .9747(\quad .8678)$

$-12.2900(41.7878) \quad 1.1917(.8849)-15.7172(46.7539)-.7216(1.1290)$

$.4040\left(\begin{array}{llll}1.0788) & -.6445(.4726) & .8296(.4860) & .1050(.5187)\end{array}\right.$

$6.8143(3.6563)-.9290(1.0154) \quad 3.1653(1.1072) \quad .6134(1.2855)$

$\begin{array}{llllll}-17.0409(41.6075) & 2.2620(.8641) & 2.5464(.9368) & 1.1231(.9317)\end{array}$

$-3.5652(2.5218) \quad 1.5614(.8773)-15.5808(51.5465) \quad 2.5849(1.5127)$

$\begin{array}{llllll}-.3796(.7360) & .1196(.4759) & .0318(.4892) & 1.7881( & .6554)\end{array}$

$\begin{array}{llllll}-.3330(.8358) & .2015(.5646) & -.0926(.6474) & 1.1596(.8529)\end{array}$

$-1.4408(1.0138)-.2607(.7006)-.1772(.9340) 1.7901(.8625)$

$1.7931(1.2984)-.0898(.4166)-.2390(.4963) \quad .4020(.5803)$

$2.3706(1.7308)-.7639(.7230)-.1375(.6797) \quad .4264(.8401)$

$1.0144(1.7601)-1.2807(.9571)-.2575(.9162)-15.7520(47.0929)$

$-1.9203(1.1745) \quad 1.1998(.6782) \quad 1.3962(.8356) \quad 1.2648(.8412)$

$-.7836(3.1519)-2.6251(1.0634) \quad 2.0133(1.1815) \quad 2.8598(1.4582)$

$-.5225(1.6431)-2.2985(1.0427) \quad 7.4039(1.8941)-2.0093(1.4501)$

$-3.9834(2.0543)-2.6167(1.0912)-4.4159(1.4047)-5.6293(1.8928)$

$\begin{array}{llllll}-1.6219(.8971) & 1.9506(.6389) & .0509(.7469) & 1.1341(.7077)\end{array}$

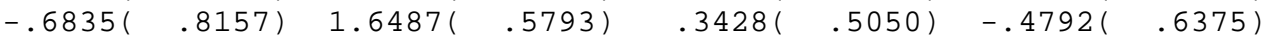

$.1159(.8002) \quad 1.0006(.4917) \quad 1.3035(.7248) 1.0799(.5675)$

$\left.\begin{array}{lllllll}-.6636(.6398) & -.1589( & .5093) & .5487( & .6771) & 2.8378( & .6332\end{array}\right)$

$\begin{array}{llllll}-1.8516(.9302) & 2.0275(.6150) & -.8305(.4790) & -.6022(.6012)\end{array}$

$.4752(.7442)-.0860(.3791)-.8875(.4928)-2.1862(\quad .5701)$

$-7.3232(4.1944)-.6818(1.4236) \quad 1.7674(2.1764) \quad 8.9239(2.6503)$

$14.1082(7.4872) \quad 2.6516(2.2631)-1.3384(3.9397)-13.6979(4.5774)$

$-7.1187(4.0840)-1.8980(1.3441)-.0583(2.3688) 6.3147(2.4340)$ 


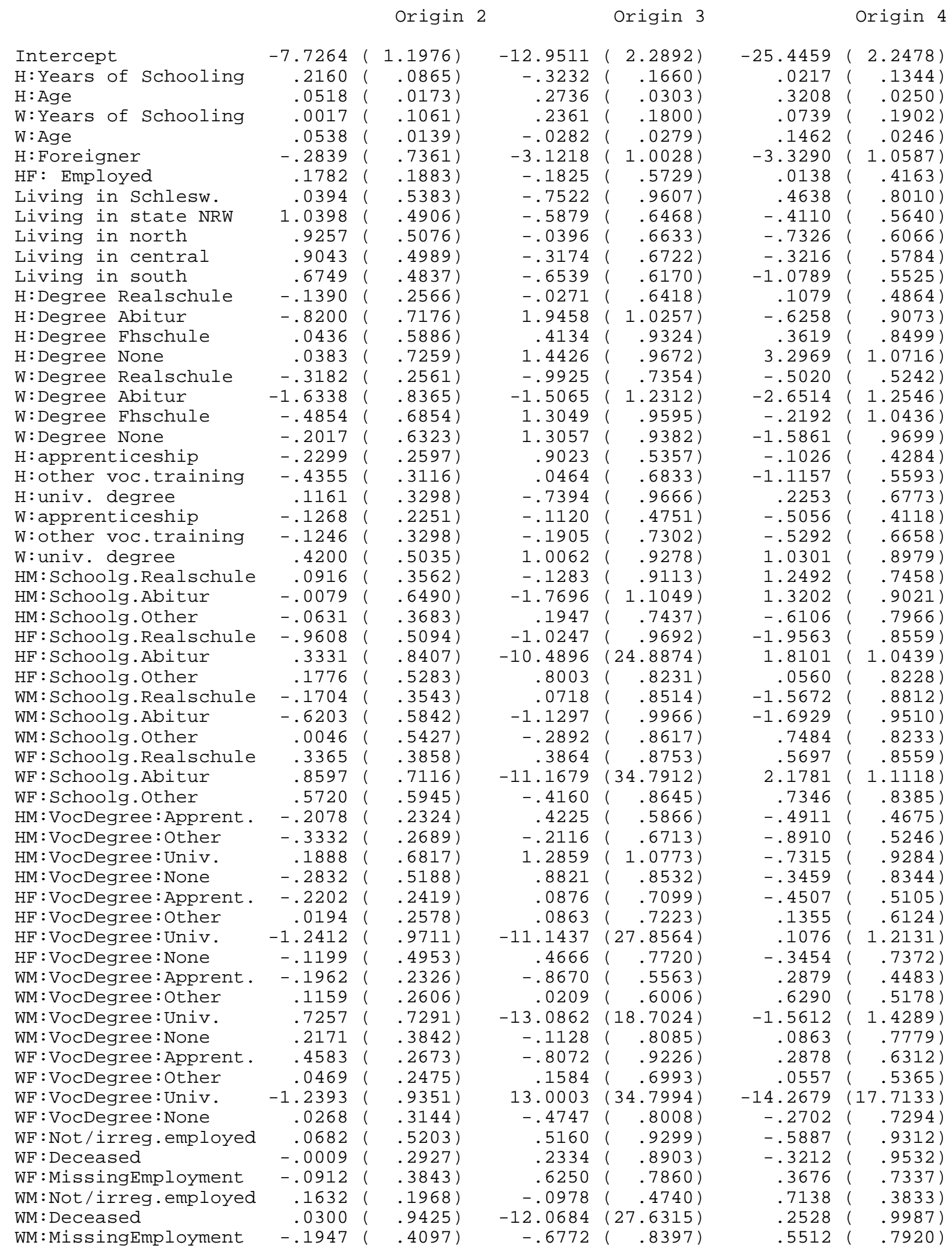

Note:

$$
\begin{aligned}
& \text { H: stands for husband } \quad F: \text { stands for father of } H \text { or } W \\
& \text { W: stands for wife. } \\
& \text { Estimation Results: Unobserved heterogeneity }
\end{aligned}
$$


RHO: FACTOR LOADINGS: FACTOR; EQUATION

$\begin{array}{rrrrr}1 & 1 & 1.0000 & ( & .0000) \\ 1 & 2 & .8390 & ( & .1980) \\ 1 & 3 & 1.5127 & ( & .1859) \\ 1 & 4 & .0368 & ( & .1485) \\ 1 & 5 & 2.4994 & ( & .5183) \\ 1 & 6 & .4269 & ( & .2489) \\ 1 & 7 & 2.9700 & ( & .4310) \\ 1 & 8 & 1.3933 & ( & .3384) \\ 1 & 9 & .6632 & ( & .2458) \\ 1 & 10 & 1.6848 & ( & .4598) \\ 1 & 11 & 2.4337 & ( & .4344)\end{array}$

FACTOR, BRANCH, HETCOEF, STD. ERR., ADDHET, STD. ERR PW

$\begin{array}{lccccccc}1 & 1 & .0000 & (.0000) & -.8265 & -5.3083 & (\star \star \star \star \star \star *) & .0002 \\ 1 & 2 & -20.4801 & (.0000) & -.8265 & 3.2735 & (.1797) & .9633 \\ 1 & 3 & .0000 & (.0000) & .8265 & .0000 & (.0000) & .0365\end{array}$

SCALE AND STD ERR FOR FACTOR 1 1 $1.6529 \quad .1656$ 
Table A-4: Monthly Log Wage and Selectivity Equations for Husbands

\begin{tabular}{|c|c|c|c|c|}
\hline $\begin{array}{c}\text { Number of } \\
\text { lwage }\end{array}$ & $\begin{array}{c}= \\
\text { Coef. }\end{array}$ & $\begin{array}{l}948 \\
\text { Std. Err. }\end{array}$ & z & $\mathrm{P}>|\mathrm{z}|$ \\
\hline $\begin{array}{r}\text { meduc2 } \\
\text { meduc3 } \\
\text { meduc4 } \\
\text { mexp } \\
\text { mexp2 } \\
\text { mtenure } \\
\text { mchron } \\
\text { mhanddum } \\
\text { _cons }\end{array}$ & $\begin{array}{r}.1428647 \\
.1875333 \\
.656293 \\
-.0121486 \\
.0001637 \\
.0069608 \\
.0184996 \\
-.029245 \\
7.823734\end{array}$ & $\begin{array}{r}.0117677 \\
.0164069 \\
.0170045 \\
.0025031 \\
.000035 \\
.0004217 \\
.0099409 \\
.0119006 \\
.0483922\end{array}$ & $\begin{array}{r}12.140 \\
11.430 \\
38.595 \\
-4.853 \\
4.681 \\
16.507 \\
1.861 \\
-2.457 \\
161.673\end{array}$ & $\begin{array}{l}0.000 \\
0.000 \\
0.000 \\
0.000 \\
0.000 \\
0.000 \\
0.063 \\
0.014 \\
0.000\end{array}$ \\
\hline $\begin{array}{r}\text { probit } \\
\text { mage } \\
\text { mage } 2 \\
\text { meduc } \\
\text { mfor } \\
\text { mexp } \\
\text { mchron } \\
\text { mhanddum } \\
\text { _cons }\end{array}$ & $\begin{array}{r}.1943178 \\
-.0029314 \\
.0787257 \\
.0250945 \\
.047182 \\
-.2509245 \\
-.246923 \\
-3.748667\end{array}$ & $\begin{array}{l}.0336608 \\
.0002875 \\
.0056552 \\
.0320104 \\
.0015381 \\
.0273039 \\
.0303191 \\
.9774998\end{array}$ & $\begin{array}{r}5.773 \\
-10.196 \\
13.921 \\
0.784 \\
30.676 \\
-9.190 \\
-8.144 \\
-3.835\end{array}$ & $\begin{array}{l}0.000 \\
0.000 \\
0.000 \\
0.433 \\
0.000 \\
0.000 \\
0.000 \\
0.000\end{array}$ \\
\hline
\end{tabular}

Table A-5: Monthly LogWage and Selectivity Equations for Wives

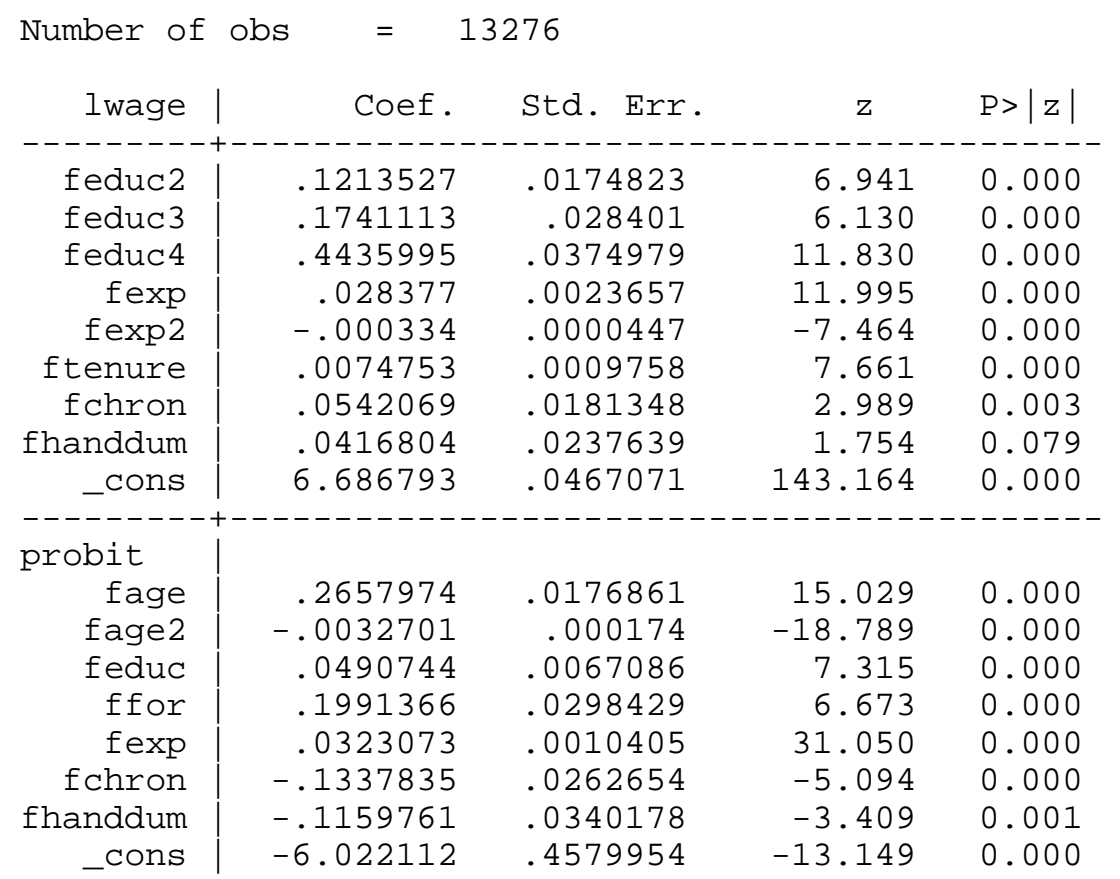

Table A-6: Monthly Log Benefit Prediction Equation for Husbands

Number of obs $=1386$

\begin{tabular}{|c|c|c|c|c|}
\hline lrente & Coef. & Std. Err. & $t$ & $P>|t|$ \\
\hline gebjahr & -.0065904 & .0014899 & -4.423 & 0.000 \\
\hline foreign & -.3878101 & .0508368 & -7.629 & 0.000 \\
\hline contry & .0238365 & .0083102 & 2.868 & 0.004 \\
\hline contry 2 & -.0002757 & .0001021 & -2.701 & 0.007 \\
\hline educ & .0757049 & .0072945 & 10.378 & 0.000 \\
\hline durtra & .0120334 & .0055526 & 2.167 & 0.030 \\
\hline
\end{tabular}




\begin{tabular}{r|rrrr} 
durfte & .002939 & .0026165 & 1.123 & 0.262 \\
evmarr & .1636593 & .0422949 & 3.869 & 0.000 \\
_cons & 18.40584 & 2.906949 & 6.332 & 0.000
\end{tabular}

Table A-7: Monthly Log Benefit Equation for Wives

\begin{tabular}{|c|c|c|c|c|}
\hline Irente & Coef. & Std. Err. & $t$ & $P>|t|$ \\
\hline gebjahr & .0071647 & .0019779 & 3.622 & 0.000 \\
\hline foreign & .0666097 & .0932932 & 0.714 & 0.475 \\
\hline contry & .0347989 & .0055753 & 6.242 & 0.000 \\
\hline contry2 & -.0003935 & .0000936 & -4.206 & 0.000 \\
\hline educ & .1157427 & .012259 & 9.441 & 0.000 \\
\hline durtra & .0090504 & .0113744 & 0.796 & 0.426 \\
\hline durfte & .01365 & .0025272 & 5.401 & 0.000 \\
\hline evmarr & -.2323707 & .0540563 & -4.299 & 0.000 \\
\hline _cons & -9.365118 & 3.783548 & -2.475 & 0.013 \\
\hline
\end{tabular}

Table A-8: Equation for Wives Probability of Receiving Benefits, Conditional on Nonemployment

\begin{tabular}{|c|c|c|c|c|}
\hline fben & Coef. & Std. Err. & $\mathrm{z}$ & $P>|z|$ \\
\hline fage & -.3333629 & .1604927 & -2.077 & 0.038 \\
\hline fage2 & .001907 & .0031138 & 0.612 & 0.540 \\
\hline fage 3 & .0000213 & .0000196 & 1.083 & 0.279 \\
\hline fcontry & -.018726 & .0151639 & -1.235 & 0.217 \\
\hline fhhsize & -.116119 & .0212274 & -5.470 & 0.000 \\
\hline fcohort & -.0098998 & .0059295 & -1.670 & 0.095 \\
\hline ffor & .1363416 & .0592635 & 2.301 & 0.021 \\
\hline fexp & .0103316 & .0023009 & 4.490 & 0.000 \\
\hline facon & .0007695 & .0002489 & 3.092 & 0.002 \\
\hline _cons & 26.41858 & 12.04351 & 2.194 & 0.028 \\
\hline
\end{tabular}

Variables not Previously Defined for Tables A-4 through A-8 (_indicates $m$ for male and $\mathrm{f}$ for female)

\begin{tabular}{ll}
\hline contry & Contribution years to retirement insurance \\
contry2 & Contribution years to retirement insurance squared \\
durtra & Number of years spent in training \\
durfte & Years of full time employment experience \\
educ & Years of education \\
evmarr & Dichotomous indicator if ever married \\
facon & Interaction: Wife's age * number of contribution years to retirement insurance \\
fhhsize & Number of persons in wife's household \\
foreign & Person is of nongerman nationality \\
_age & Individuals' age \\
_age2 & Individuals' age squared \\
_age3 & Individuals' age cubed \\
_chron & Dichotomous indicator whether suffering from a chronic disease \\
_cohort & Birth year \\
_educ2 & Years of education: Between 10 and 11. \\
_educ3 & Years of education: Between 12 and 13. \\
_educ4 & Years of education: At least 14.
\end{tabular}


_exp

-exp2

for

gebjahr

_handdum

_tenure
Labor force participation experience

Labor force participation squared

Dichotomous indicator of whether of nongerman nationality

Individual's birth year

Dichotomous indicator of whether is andicapped

Tenure in current job 


\section{Table A-9: List of Specification Tests}

Notes: $\quad$ (1) The $\chi^{2}$ statistics are for tests of the null hypothesis that the specification in a given column provides an adequate fit against the alternative specification in the next column to the right.

(2) A * indicates that the hypothesis is rejected at the five percent level. A --- indicates that the test statistic could not be computed becuase the specification failed to converge.

(3) The specifications in one panel cannot generally be compared to the specifications in other panels. The "baseline" specification has continually been modified based on the test results.

A. $\quad$ Tested: Number of points of support in the distribution of $\mu$

\begin{tabular}{|c|c|c|c|c|c|}
\hline & & one & two & three & four \\
\hline $\log L$ & & -8328.9 & -8253.4 & -8248.3 & -8248.7 \\
\hline No. of & parameters & 644 & 656 & 658 & 660 \\
\hline$\chi^{2}(\mathrm{df})$ & & $151.0(12)^{*}$ & $10.2(2)^{*}$ & --- & \\
\hline
\end{tabular}

B. Tested: Geographic indicators

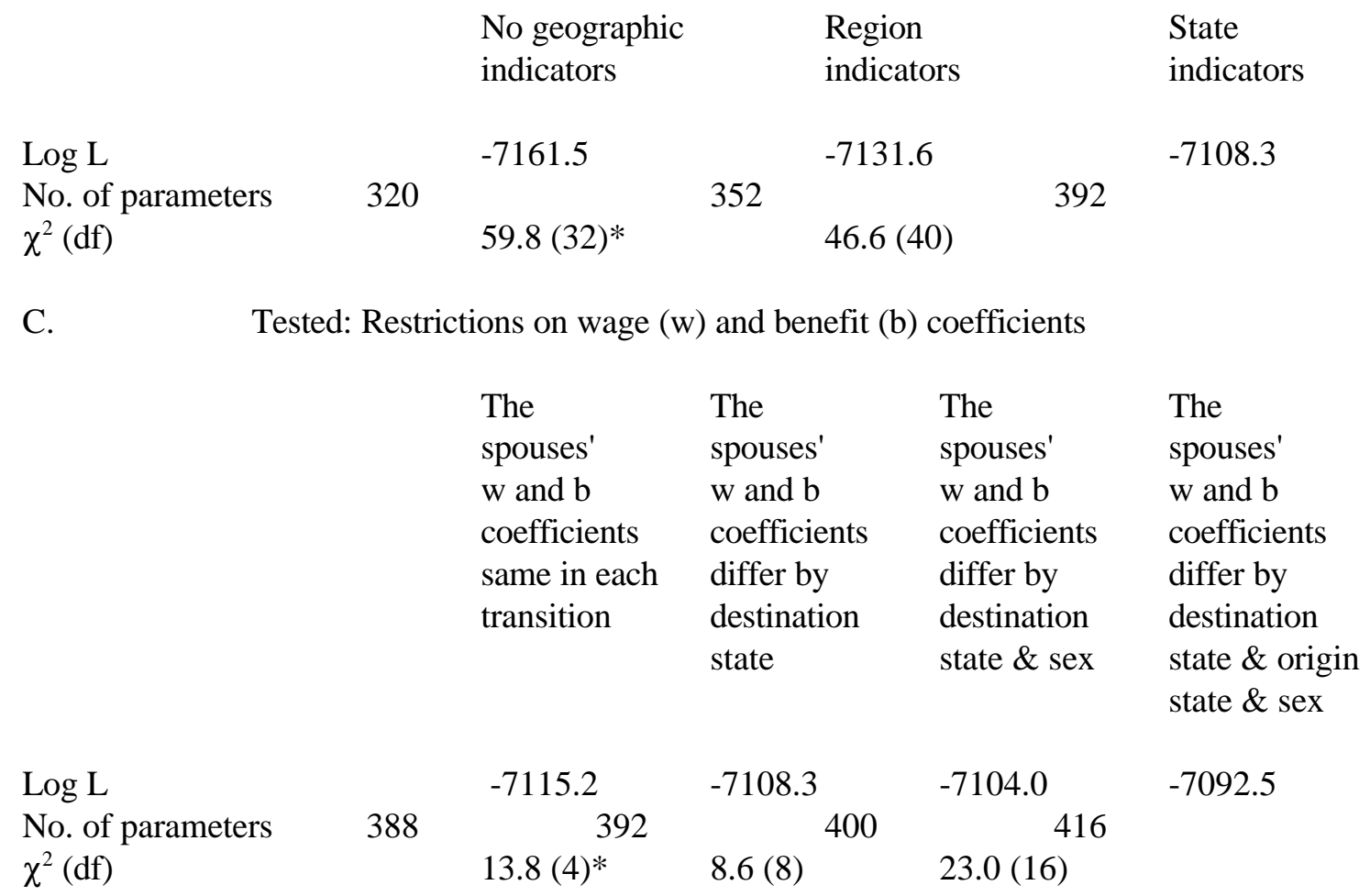


D. Tested: Specification of history dependence of couples' transitions

\begin{tabular}{|c|c|c|c|c|}
\hline & & $\begin{array}{l}\text { No lagged } \\
\text { states in } \\
\text { specificat. }\end{array}$ & $\begin{array}{l}\text { Ever previously } \\
\text { in each state }\end{array}$ & $\begin{array}{l}\text { Ever previously } \\
\text { in each state } \\
\& \text { in last state }\end{array}$ \\
\hline $\log \mathrm{L}$ & & -7097.8 & -7041.2 & -7033.3 \\
\hline $\begin{array}{l}\text { No. of parameters } \\
\chi^{2}(\mathrm{df})\end{array}$ & 384 & $\begin{array}{r}400 \\
\end{array}$ & & 416 \\
\hline$\chi^{2}(\mathrm{df})$ & & $113.2(16)^{*}$ & $15.8(16)$ & \\
\hline
\end{tabular}

E.

Tested: Alternative Health Measures

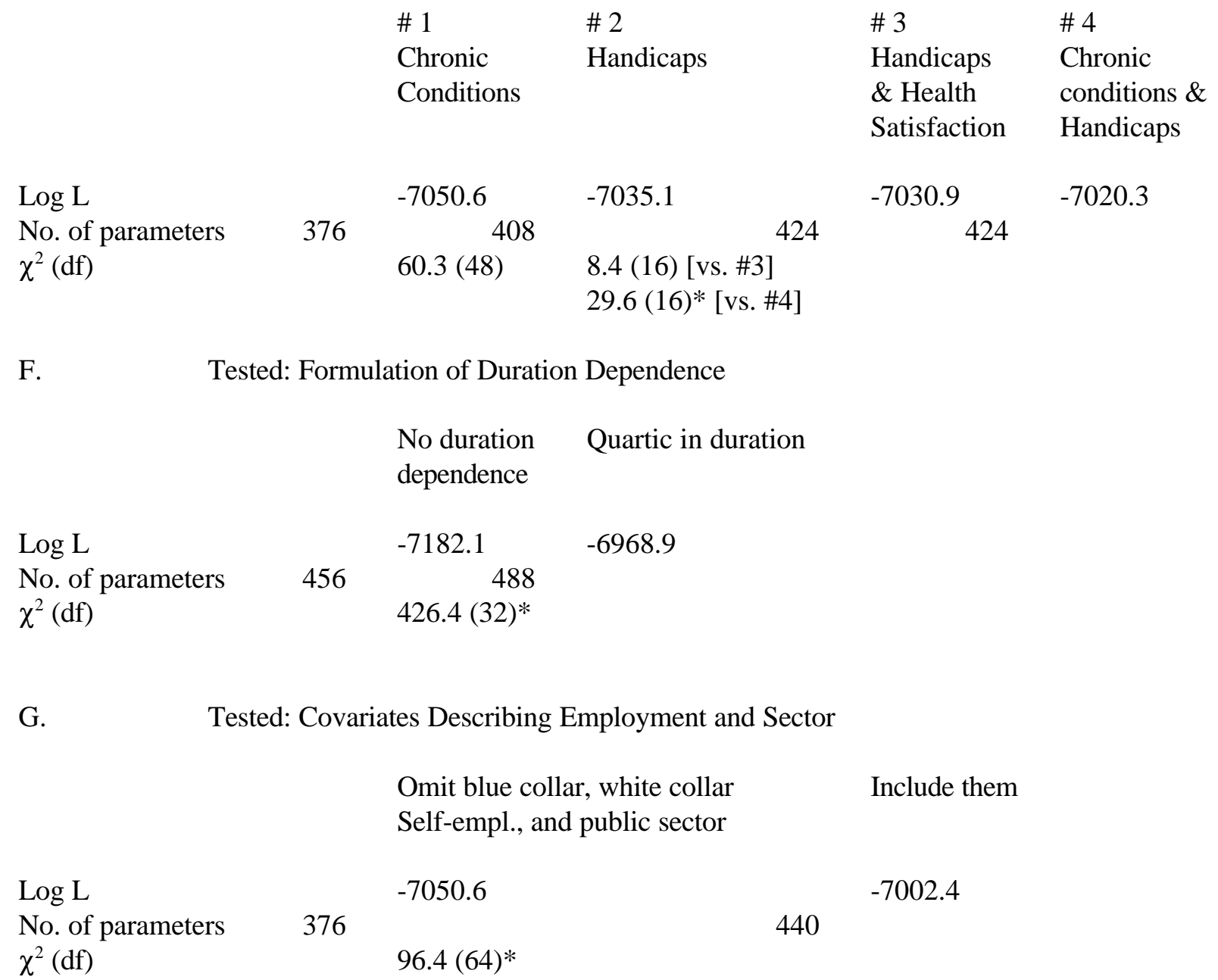


H. Tested: Formulation of Age Effects

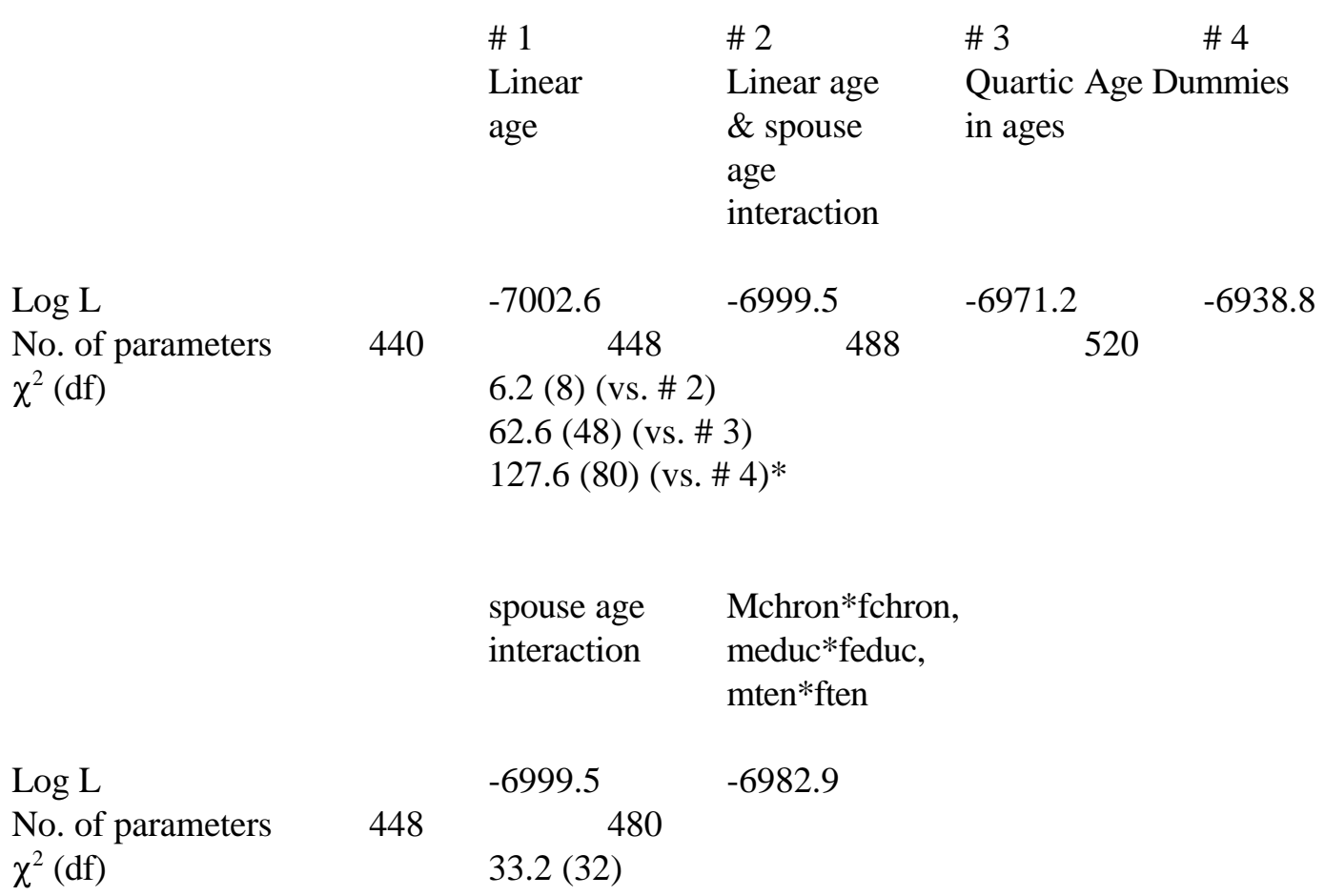

